\title{
A REVISION OF THE INDO-WEST PACIFIC SPINY LOBSTERS OF THE PANULIRUS JAPONICUS GROUP
}

\author{
by \\ R. W. GEORGE \\ Western Australian Museum, Perth, Western Australia \\ and

\section{B. HOLTHUIS} \\ Rijksmuseum van Natuurlijke Historie, Leiden, Netherlands
}

\section{INTRODUCTION}

As a result of separate investigations on Panulirus japonicus (sens. lat.), the present authors independently came to the conclusion that more than one species was included under that name. The first author (George), when in $195^{8}$ studying specimens of the Western Australian spiny lobster which at that time was indicated by the name Panulirus longipes (A. Milne Edwards) (a species considered by many authors to be synonymous with $P$. japonicus), was dissatisfied with that identification and obtained material of the typical $P$. longipes from Zanzibar. Comparison with this material showed that the Western Australian spiny lobster represented an unnamed species, which he then described as $P$. cygnus. He also arrived at the conclusion that $P$. japonicus and $P$. longipes are separate species and that the latter perhaps should also be split up.

The second author (Holthuis), during a year's visit (1952-1953) to the U.S. National Museum in Washington, D.C., was struck by the fact that the colour pattern of "Panulirus japonicus" from Hawaii is strikingly different from that of the typical Japanese $P$. japonicus, a difference that proved to be constant. He also found the colour pattern of $P$. longipes to be strikingly different from that of the typical $P$. japonicus, and further discovered constant morphological differences between the three forms, which convinced him that they represented three valid species. These finds were verified later with the collections of the Leiden Museum, where the types of $P$. japonicus are preserved; it was then decided to make a revision of the entire $P$. japonicus group. In the meantime E. P. Reed described a new species $P$. pascuensis from Easter Island, which also proved to belong 
to the $P$. japonicus complex. Of this species Holthuis obtained two specimens on loan from the Brussels Museum and during a second visit to Washington (1959-1960), he examined two more specimens in the U.S. National Museum, where then also all other material of the group was carefully examined or re-examined.

Each of the two authors had only representatives of part of the forms of the $P$. japonicus group at his disposal, but together they covered the whole group quite thoroughly. Collections of a number of Museums were studied, thus George examined material preserved in the Australian Museum, Sydney (AM), the British Museum (Nat. Hist.), London (BM), the Division of Fisheries of Port Moresby, Papua (DFPM), the Western Australian Museum, Perth (WAM), and the Queensland Museum, Brisbane (QM). Holthuis examined the material of the British Museum (Nat. Hist.) (BM), the Institut Royal des Sciences Naturelles de Belgique, Brussels (ISNB), the Museum of the Academy of Natural Sciences, Philadelphia (ANSP), the Rijksmuseum van Natuurlijke Historie, Leiden (RMNH), the U.S. National Museum, Washington, D.C. (USNM), and the Zoologisch Museum of Amsterdam (ZMA). The initials given in parentheses after the names of the institutions are used in the rest of the text to indicate these institutions.

Both authors wish to express here their great appreciation to the staff of the above institutions for the most cordial co-operation and assistance. Valuable help was also received from persons providing material and information which enabled the authors to solve most of their problems; in this connection the authors are in particular grateful to Dr. Tucker Abbott of Philadelphia, Dr. A. J. Bruce of Hongkong, Dr. A. Capart of Brussels, Dr. Fenner A. Chace of Washington, D.C., Dr. G. H. P. De Bruin of Ceylon, Dr. Isabella Gordon of London, Dr. E. Harada of Seto, Japan, Dr. E. P. Hodgkin of Perth, Dr. I. Kubo of Tokyo, the late Mr. G. Mack of Brisbane, Mr. F. A. McNeill of Sydney, Mr. R. Pahl of Fiji, Dr. R. B. Pike of Wellington, New Zealand, Dr. E. B. Reed of Valparaiso, Chile, Dr. T. Richert of Hawaii, and Dr. J. H. Stock of Amsterdam.

In the material examined the length given is the carapace length (cl.), which is measured in the mid line of the carapace from the posterior margin to the anterior ridge which runs transversely just in front of the supraorbital spines.

The Indo-West Pacific species of Panulirus White, i847

In I9 I A. Gruvel published a fundamental monograph of the Palinuridae. Later De Man (1916) and Holthuis (1946) gave revised lists of the species 
of Palinuridae then known to them. In the more recent of these lists seven species of Panulirus inhabiting the Indo-West Pacific region were recognised. As a result of the examination of material in the collections of several museums in America, Europe and Australia, we have found that under the name Panulirus japonicus (Von Siebold), Holthuis (1946) included three species. Further, two new species, closely related to $P$. japonicus, have been described by Reed (1954) and George (I962) since the publication by Holthuis. This would bring the total up to I I, but Gordon (I953) concluded that Panulirus homarus (L.) is a variable species and included forms formerly regarded as a distinct species, $P$. dasypus (Latreille). Her arguments that $P$. homarus and $P$. dasypus are synonymous are very convincing and we follow her in referring the name $P$. dasypus to the synonymy of $P$. homarus. Finally Holthuis in 1962 described a new species of Panulirus, $P$. stimpsoni from Hongkong. This species belongs in the group of Panulirus versicolor (Latreille) and $P$. ornatus (Fabricius).

The total number of Indo-West Pacific species of Panulirus now recognised by us thus amounts to eleven.

The following two keys may be used for the separation of these eleven species. The first uses mainly morphological characters, while the second is based exclusively on characters provided by the colour pattern of the animals. As the colour pattern of most Panulirus species persists, even in spirit material, this last key may prove to be useful in the identification of both fresh and preserved animals.

Key to the Indo-West Pacific species of Panulirus based on morphological features

I. Each abdominal somite with a transverse groove . . . . . . . . . . . 2

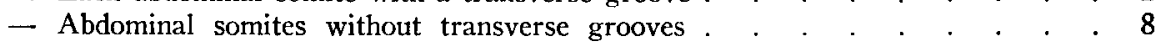

2. Anterior margin of abdominal transverse grooves crenulate . . P. homarus (L.)

- Anterior margin of abdominal transverse grooves not crenulate . . . . . . 3

3. Antennular plate with 4 equal principal spines, which are fused at the base . $P$. penicillatus (Olivier)

- Antennular plate with two principal spines . . . . . . . . . . 4

4. Transverse grooves of abdominal somites III and IV do not join the corresponding pleural grooves. Pleopods of second abdominal somite of male with endopod and exopod . . . . . . . . . . . . . . . . . P. japonicus (Von Siebold)

- Transverse grooves of abdominal somites III and IV join the corresponding pleural grooves. Pleopods of second abdominal somite of male without endopod 5

5. Transverse groove of abdominal somite II does not join the pleural groove $P$. pascuensis Reed

-- Transverse groove of abdominal somite II joins pleural groove . . . . . . . 6

6. Anterior margin of pleuron of abdominal somite II with a series of distinct teeth, abdomen transversely banded. . . . . P. marginatus (Quoy \& Gaimard)

- Anterior margin of pleuron of abdominal somite II without teeth, abdomen dorsally spotted 
7. Posterior margin of thoracic sternum of adult female with two distinct teeth, posterior half of abdominal somite II without pubescent area.

P. longipes (A. Milne Edwards)

- Posterior margin of thoracic sternum of adult female without teeth, abdominal somite II with a transverse band of pubescence behind the transverse groove

$P$. cygnus George

8. Flagellum of exopod of second maxilliped well developed, multi-articulate .

P. polyphagus (Herbst)

- Flagellum of exopod of second maxilliped small or absent .

9. Groove before the posterior margin of the carapace narrower than the marginal ridge behind it, of about the same width throughout. Abdomen smooth and naked, without narrow transverse pale bands . . . . . P. ornatus (Fabricius)

- Groove before posterior margin of the carapace at least as wide as the marginal ridge, widened in middle. Abdomen with or without sunken pubescent areas and with or without narrow transverse pale bands . . . . . . . . . . . . Io

Io. Abdominal somites with distinct sunken pubescent areas. Fifth pleopod of male about twice as long as wide. Abdomen rather uniformly covered with minute pale speckles, without transverse pale bands... . . .P. stimpsoni Holthuis

- Sunken pubescent areas usually absent from abdomen or indistinct. Fifth pleopod of male about three times as long as wide. Abdomen with conspicuous narrow transverse pale bands... . . . . . . . . P. versicolor (Latreille)

\section{Key to the Indo-West Pacific species of Panulirus based on colour markings}

I. Abdomen with narrow transverse pale bands .

- Abdomen without narrow transverse pale bands .

2. Legs striped

- Legs not striped

3. Carapace with spots

- Carapace with lines of colour

4. Merus of pereiopods plain, joints ringed .

- Merus of pereiopods blotched or spotted.

5. Dorsal surface of abdomen, apart from a white spot behind each of the articulations of the somites, unspotted or with a few very small and indistinct spots on anterior somites only; general impression of the abdomen as being of uniform colour 6

- Dorsal surface of all abdominal somites with distinct spots . . . . . . . 7

6. Pereiopods with transverse coloured rings or with large irregular spots $P$. ornatus

- Pereiopods with longitudinal colour stripes . . . . . . . P. japonicus

7. Abdomen with a moderate number of moderate sized spots on the dorsal surface 8

- Abdomen with very many fine spots on dorsal surface . . . . . . . . . 9

8. Carapace brightly spotted and marked . . . . . . . . . . P. longipes

- Carapace plain. . . . . . . . . . . . . . . . P. cygnus

9. Legs spotted or blotched . . . . . . . . . . . . P. homarus

- Legs striped . . . . . . . . . . . . . . . . . . . . . . . . . . . . Io

Io. Outer surface of merus of pereiopods with 3 or more pale lines, outer surface of propodus with 2 lines. Abdominal pleura uniformly spotted, without white line. No conspicuous large pale spot behind the articulation of the abdominal somites

$P$. penicillatus

- Outer surface of merus of pereiopods with one or two white lines, which may be strongly reduced; outer surface of propodus with one line which may be largely absent. Abdominal pleura with a white line extending upward from the tip. Behind 
each of the articulations of the abdominal somites a large and conspicuous white spot (only those on the second somite rather narrow) . . . . P. stimpsoni

\section{The Panulirus japonicus group}

The $P$. japonicus-group consists of five species of Panulirus all of which inhabit the Indo-West Pacific region: $P$. japonicus, $P$. longipes, $P$. cygnus, $P$. marginatus, and $P$. pascuensis. This homogenous group is characterized by having ( $I$ ) the exopod of the second and third maxilliped well developed and provided with a distinct flagellum, (2) the abdominal somites provided with a deep uninterrupted straight transverse groove, which extends over the full breadth of the somite and bears a dense fringe of posteriorly directed short hairs, and (3) the antennular plate provided with two principal spines. The group shows a close resemblance to the guttatus-group of the Atlantic, which consists of two species, $P$. guttatus (Latreille) and $P$. echinatus Smith. The species in this latter group, as well as the other closely related species, the Indo-West Pacific $P$. penicillatus (Olivier), can, however, immediately be distinguished by that the exopod of the third maxilliped has no flagellum. The group also resembles the East Pacific $P$. interruptus and the West Atlantic $P$. argus in the form of the exopod of the third maxilliped but these two species can be distinguished immediately by the interrupted transverse abdominal grooves.

The differences between the five species of the japonicus-group are not very conspicuous and this evidently has been the reason that they have been synonymised for so long. In the spinulation of the carapace no striking differences could be found, but the nature of the grooves of the abdomen provides some good differential characters. In addition to the transverse groove which extends over the middle of each somite and which reaches on to the pleura, there is a second groove, here named "pleural groove". This pleural groove starts near the anterior articulation of the abdominal somite and runs about parallel to the anterior margin of the pleuron, it may ultimately curve posteriorly and slightly upward. In some species the transverse and pleural grooves are in contact, in others the transverse groove of some abdominal somites stops before it reaches the pleural groove. On the first abdominal somite there is a triangular plate, here named "plate D", which lies above and slightly in front of the pleuron; anteriorly this plate is delimited by a deep depression which separates the sunken anterior part of the somite (i.e., the part which is covered by the carapace in the fully extended animal) from the high posterior part of the somite. This plate in some species forms an undivided triangle, while in others it may be incised or even bisected by a groove which is a continuation of the 
pleural groove. Other differences between the species of the japonicusgroup are found in the presence or absence of spinules on the anterior margin of the second pleura, in the presence or absence of pubescent areas on the abdominal somites, in the spinulation of the antennular plate, in the shape of the posterior margin of the female sternum, and in the first pleopods (i.e., the pleopods of the second abdominal somite) of the males. The most striking characters, however, are provided by the colour patterns of the animals.

Panulirus japonicus (Von Siebold, I824) (text-fig. Ia; pl. I)

Palinurus Japonicus Von Siebold, I824: 15; Von Siebold, 1826: 20; Herklots, 186I : I43; Von Martens, 1876: 142, 147.

Palinurus japonicus De Haan, I841 : 157, 158, pl. 41/42; De Haan, I844: pl. L,M ; Heller, I865: 95; Albert, I883: 51; Albert, I883a: 496, pl. 30 fig. 20, 22, 23; Doflein, 1906a: 67; Okuda, 1919: 56; Holthuis, 1956: 55; Hemming, 1958: 199.

Panulirus Japonicus White, 1847 : 69; p.p. Gruvel, I9II: 28, text-fig. II, pl. 5 fig. I (on: 56 as Panulirus japonicus variété indo-japonaise).

Panulirus japonicus Stimpson, 1860: 24; Hattori \& Oisi, 1899; Doflein, 1900: 129; Hattori \& Oisi, 1901; Thompson, 1901: 18; Doflein, 1902: 643; Rathbun, 1902: 37; Doflein, I906: 148, 198; (var. japonaise) Gruvel, 1911a: 1351; Balss, 1914: 77; Tokuhisa, I914: 41; p.p. Pesta, I915: Io; Terao, 1915; p.p. De Man, 1916: 33, 44; Nakazawa, I917: 259, pl.; Parisi, I917: 8; Terao, 1919: I, pl. I-4; Maki \& Tsuchiya, 1923: 79, pl. 7 fig. I; Terao, I925: I ; Komai, Akatsuka \& Ikari, I927: 294; Komai \& Ikari, 1929: 121; Terao, 1929: 387, pl. I1-15; Ping, 1930: 136; Kinoshita, 1931 : 23I ; Kinoshita, I931a; Yosii, I931 : 445, fig. I-3; Kinoshita, 1932; Kinoshita, I933: 237, fig. I; Yosii, 1933: 233, fig. I-8; Kinoshita, 1934: 4191; Fisheries Society of Japan, 1935: vol. 2, pl. 59 fig. 3; Ohshima, 1935: 75; Niiyama, 1936: 21, fig. I-12; Niiyama, 1936a: 53; Kikuti, I937: 7; Nakamura, 1937; Kubo, 1938: IOI, text-fig. I-4, pl. I; Kikuti, I939; Kubo, 1939: 138; Takayama, 1939; Kubo, 1940: 287; Nakamura, I940: IoI, fig. I, 2; Ohshima, 1941 : 231 ; Yoshida, 1941 : 3I, pl. 8 fig. I; Ohshima, I942: 36; p.p. Holthuis, 1946: I23, pl. I I fig. n; Okada \& Kato, 1946: I; Okada \& Kubo, 1946: I; Ino, 1947: 32; Kubo \& Hattori, 1947: 108; Okada, Kubo \& Takagi, 1947: 27; Ohshima, 1948: 210; Okada \& Kubo, I948: 20, fig. I, 2; p.p. Chace \& Dumont, I949: 4, I0; p.p. York, 1949: I ; Ino, I950: 725; Kubo, 1950: 91 ; Okada \& Kubo, 1950: 41, fig. 3, 4; Shiino, 1950: I, pl. I-25; Okada, 1951 : 85; Gordon, 1953: 17; Kubo, 1953: 30, fig. A-D; Anon., I954: 760, fig. 2191; Kubo, 1954: 97, fig. I; Masuda, 1954: 1007, fig. I ; p.p. Popovici \& Angelescu, 1954: 508; Konishi, 1955: I38; Matsui, I955: 23I, fig. 1-19; Matsui, 1955a: 257, fig. I-5; Esaki, 1956: 266; Kubo, 1956: 396, fig. 8; Utinomi, 1956: 61, pl. 30 fig. I; Harada, 1957: 99, text-fig. I-6, pl. 6, 7; Matsui, 1957: 148, fig. I-12; Matsui \& Shibuya, 1958: 189, fig. I-8; Okada, Taki, Sakai \& Abe, 1958: 143, fig. 257; p.p. F. G. W. Smith, I958: 8; Harada, 1959: 57, fig. I ; Liu, 1959: 36; Niiyama, 1959: 5, 7, 45; Yamaji, 1959: 23, 65, figs.; Kubo, I960: Ior, pl. 50 fig. 2; Kubo, 196r: 1063, fig. I-3; Kubo, 1962: 322, fig. I-3.

Palinurus guttatus p.p. Pfeffer, i88I: 30.

Palinurus (Panulirus) japonicus Parker, 1884: 304.

Senex japonicus Ortmann, I891 : 25; Bouvier, 1899: 176.

Puer pellucidus Ortmann, I891: 37, pl. I fig. 3; Bouvier, 1905: 2; Balss, 1914: 79.

Puerulus pellucidus Calman, 1909a: 441 ; Bouvier, I913: 84; Kinoshita, 1934a: 39 r.

Panulirus japonica Chen, 1934: 11 . 


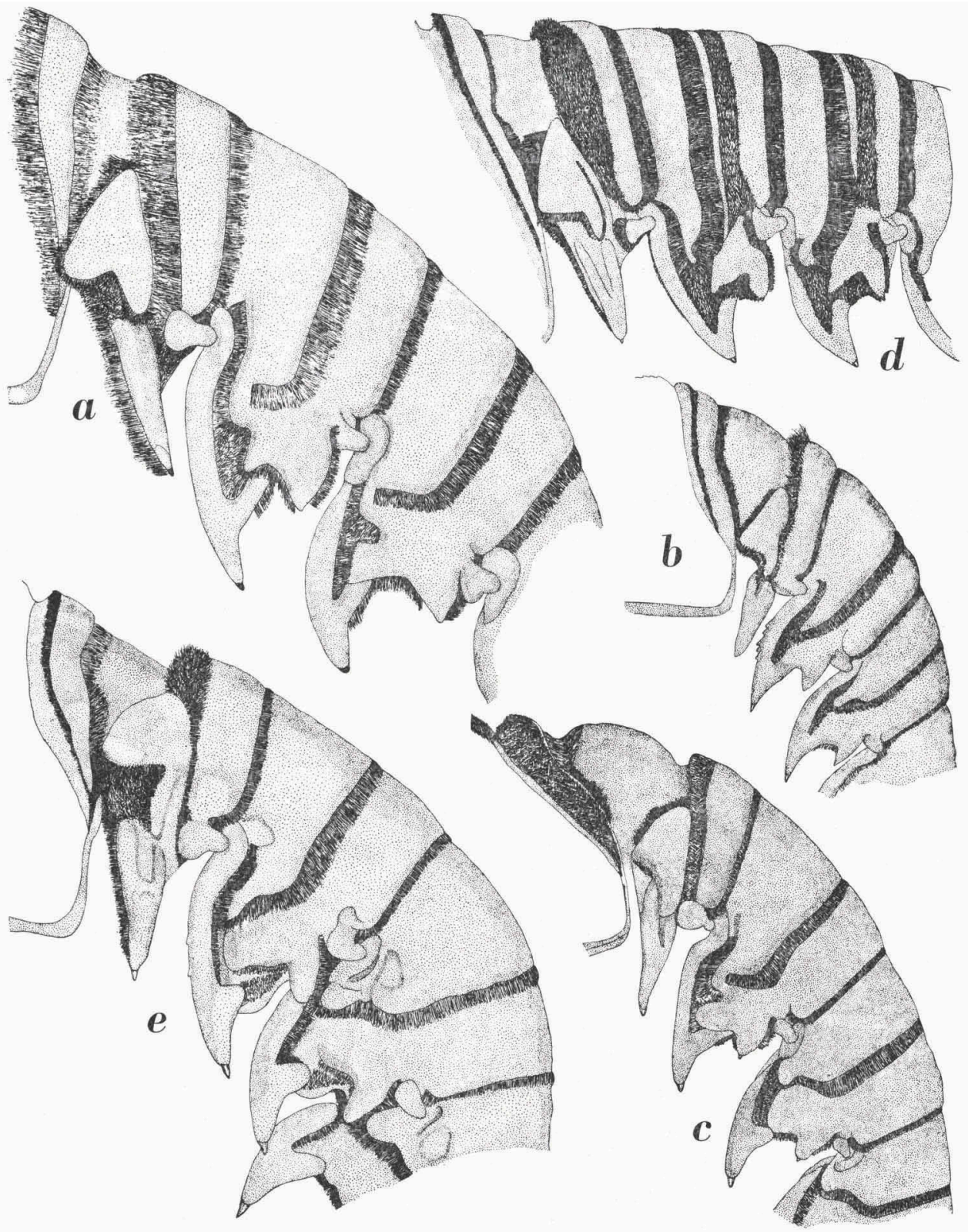

Fig. I. First to third abdominal somites in lateral view. a, Panulirus japonicus (Von Siebold), of, Shimoda, Japan (RMNH no. D. I4505) ; b, Panulirus marginatus (Quoy

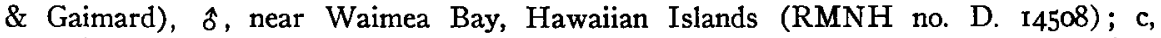
Panulirus pascuensis Reed, ô, Pitcairn Island (RMNH no. D. 20368); d, Panulirus cygnus George, \& paratype, Rottnest Island (RMNH no. D. 13107) (the groove on plate $\mathrm{D}$ is inadvertently omitted); e, Panulirus longipes longipes (A. Milne Edwards), $\hat{o}$, Ceylon (RMNH no. D. I869I). a, b, e, X I.6; c, d, natural size. J. van Leeuwen del. 
Panurilus japonicus Kinoshita, I934a: 397.

Ise ebi Kubo \& Nonaka, I955: I7, fig. I, 2.

Material examined.

Japan; 1823-I830; P. F. von Siebold; lectotype of Palinurus japonicus Von Siebold. I of cl. $108 \mathrm{~mm}$ (RMNH no. D. 960).

Japan; 1823-1830; P. F. von Siebold; paralectotypes. - 3 of cl. $62-93 \mathrm{~mm}, 2$ o cl. 43 and $45 \mathrm{~mm}$, I ovigerous $\&$ cl. $73 \mathrm{~mm}$ (RMNH no. D. I672), I \& cl. $59 \mathrm{~mm}$ (RMNH no. D. 5623, preserved dry), 29 ô cl. $43-119 \mathrm{~mm}, 2$ \& cl. $56-66 \mathrm{~mm}$ (RMNH no. D. 5624, preserved dry), 2 of cl. 77 and $98 \mathrm{~mm}$ (USNM no. 104120, preserved dry).

Japan. - I $\hat{\partial}$ cl. $66 \mathrm{~mm}$ (BM; possibly paralectotype of Palinurus japonicus Von Siebold; preserved dry).

Japan; H. Loomis. - I juvenile cl. $26 \mathrm{~mm}$ (USNM no. 21641, preserved dry).

Japan; Japanese Exhibit of World Colonial Exhibit. - I 8 cl. $98 \mathrm{~mm}$ (USNM no. 18639, preserved dry).

Japan; received 19 December I88ı; U.S.S. "Palos". - I ô cl. 46 mm (USNM no. 5293).

Japan; I4 October 1960; I. Kubo. -3 o cl. $67-69.8 \mathrm{~mm}, 3$ \% cl. 48.6-63 mm (WAM no. $126-62$ ).

Tokio, Honshu, Japan; October I896; "Albatross" Expedition. - I $9 \mathrm{cl} 50 \mathrm{~mm}$ (USNM no. 28502).

Yokohama; H. B. Joyner. $-2 \hat{\delta} \mathrm{cl}$. 60 and $6 \mathrm{I} \mathrm{mm}$ (BM no. 78-1o).

Yokohama; October Igog; G. F. Tydeman. - I o cl. $45 \mathrm{~mm}$ (ZMA no. De. Ior.8Ig).

Yenoshima, mouth of Tokio Bay; E. S. Morse. - I \& cl. $56 \mathrm{~mm}$, I $\&$ cl. $57 \mathrm{~mm}$ (USNM no. 105647).

Misaki, Sagami Bay; 1906; “Albatross" Expedition. $-2 \quad+\quad \mathrm{cl} .49$ and $73 \mathrm{~mm}$ (USNM no. 105887).

Misaki; A. V. Insole. - I $\delta$ (moulting) cl. $45 \mathrm{~mm}$, I juv. cl. $14 \mathrm{~mm}$ (BM no. I92I.12. 23.32-33).

Shimoda, Izu province, mouth of Sagami Bay, Honshu; 1853-1856; North Pacific Exploring Expedition; W. Stimpson. - I 8 cl. $5 \mathrm{I} \mathrm{mm}$, I $\&$ cl. $57 \mathrm{~mm}$ (USNM no. 210I), I of cl. $56 \mathrm{~mm}$ (RMNH no. D. I4505).

Nagasaki, Kyushu, Japan; summer I900; D. S. Jordan \& J. O. Snyder. - I ô cl. 55 $\mathrm{mm}$, I of cl. $5 \mathrm{I} \mathrm{mm}$ (USNM no. 26296).

Locality unknown. - I $q$ cl. $48 \mathrm{~mm}$ (USNM no. I0564I), I $q$ cl. $52 \mathrm{~mm}$ (USNM no. 2496 , preserved dry).

Description. - The transverse grooves of abdominal somites II to IV show an anteriorly directed median notch, which is usually rather inconspicuous and even may be entirely absent in somite IV. The transverse groove of somite $\mathrm{V}$ is straight. The transverse grooves of somites II, III, and IV are curved forward at their lateral extremities and stop rather abruptly before reaching the pleural groove with which they are not connected. In somite $\mathrm{V}$ there is a connection between the two grooves though it is often indistinct. Plate D of somite I is entire, without any incision or groove. The anterior margin of the pleuron of somite II is straight or slightly convex, it shows no spinules or teeth. Apart from the hairs along the posterior margins of the somites and those along the transverse grooves, the upper surfaces of the somites are entirely naked. 
The antennular plate bears two strong anterior spines. Behind these the plate is smooth or shows some minute, irregularly placed spinules.

In both the males and the females the thoracic sternum ends posteriorly in two distinct submedian teeth, which are placed close together.

The pleopods of the second abdominal somite in the males possess a large foliaceous exopod and an endopod which is variable in size; sometimes the endopod is large and foliaceous, sometimes small and rod-like, it is, however, always distinct.

Colour. - The general colour of the body is a dark brownish red. The general impression given by the animal is that this colour is uniform. There may be a few small and inconspicuous pale spots on the carapace. An often inconspicuous pale longitudinal streak is visible on each side of the carapace. The supra-orbital horns are dark reddish inside with a sharply defined very narrow pale strip along the anterior margin; the outer surface of the horn is similar, but has furthermore a pale streak which starts from a point near the middle of the base of the horn and widens distally, sometimes occupying practically the entire anterior half of this outer surface. The red colour of the horn is either uniform or shows some, usually inconspicuous, pale spots. The abdomen is of a uniform dark reddish colour. There are usually no spots apart from the often very distinct white spots at and just behind the articulations of the abdominal somites and at the top of plate D. Small pale spots may be present, but are so few, inconspicuous and scattered that they are only visible at a close examination and do not detract from the general impression that the abdomen has a uniform colour.,

The legs are of the same colour as the body. A rather narrow uninterrupted pale line extends over the whole length of the dorsal margin of the merus, carpus and propodus. A similar line is present on the ventral margin of these segments while both lateral surfaces show two such narrow pale lines on the merus and one on the carpus and the propodus. Though the dorsal line is always distinct and uninterrupted, the other lines are often interrupted and sometimes hardly discernable.

De Haan ( $184 \mathrm{r}: \mathrm{I}_{5} 8$ ) already described the abdomen of the species as of uniform colour: "Abdomen unicolor, impresso-punctatum, macula tantum unica flava prope articulorum latera", while the supra-orbital horns were described as follows: "Cornua frontis vel tota rubescentia vel margine superiore fusco albomaculata".

The first colour description of living specimens of this species given in a European language is the one by Von Siebold's helper and successor at the Dutch trading post at Decima, Heinrich Bürger. Bürger, who was in Decima (near Nagasaki) from 1825 to about 1835 , sent a collection of 52 
coloured plates of Japanese Crustacea and Xiphosura to Holland, 25 of these plates were accompanied each by a three or four page handwritten text. Both the plates and the text are now in the possession of the Rijksmuseum van Natuurlijke Historie. In the text accompanying plate no. 2r, showing Panulirus japonicus, the species was carefully described and several interesting observations made. Bürger's description of the colour of the living animal runs as follows (translated from the Dutch original): Reddish brown dorsally in various shades, ventrally red and yellowish white, the pleopods beautifully pale blue with narrow red margins, the tail fan yellowish with a broad reddish margin. The legs, like the body and the tail, brown and red in various shades; the hairs on the dactyls, however, are entirely yellow. Coloured figures of the present species have been published by Fisheries Society of Japan (1935), Utinomi (1956), Okada, Taki, Sakai \& Abe (1958) and Kubo ( I960).

Distribution. - Bürger's above mentioned manuscript already stated of this species: "Wordt zeer veel het geheele jaar door langs de Zuidwestkust van Japan, vooral op rotsachtige gronden, tusschen groote steenen gevangen en menigvuldig gegeten" (Is caught commonly throughout the year along the southwestern coast of Japan, especially on rocky grounds among boulders, and is eaten very frequently). This observation characterises the distribution of the species in Japan quite well. According to Kubo (1954) the species is commonly found in Japan southwards of about $35.5^{\circ} \mathrm{N}$ on the Pacific coast, and southwards of $34.5^{\circ} \mathrm{N}$ on the coast of the Japanese Sea; however, on the Pacific coast specimens are occasionally reported from as far north as about $38.5^{\circ} \mathrm{N}$, while on the coast of the Japanese Sea a find has once been reported (Tokuhisa, I9I4) from Nanao Bay at $37^{\circ}$ Io $^{\prime} \mathrm{N}$. Doflein (1906: $1_{4} 8$ ), who reported the species from Watanoha in Sendai Bight $\left(3^{\circ}\right.$ I $\left.5^{\prime} \mathrm{N}\right)$, already expressed his surprise to find the species that far north. The distribution of the species in Japan, according to the figures given by Kubo (1939, 1940) extends all the way down to the Ryukyu Islands, Okinawa Prefecture. The literature on the occurrence of the species in Japan is so extensive that it is unpractical to list here all the various published records. Outside Japan the species has rarely been reported: Korea (Yoshida, I941), East China Sea (Liu, 1959), Amoy, China (Ping, 1930; Chen, 1934), Formosa (Maki \& Tsuchiya, 1923), Tamsui, N. Formosa (Balss, I9I4; Parisi, r917). It is possible, of course that some of these records actually pertain to Panulirus longipes as is the case of so many records of "Panulirus japonicus" from other parts of the Indo-West Pacific area.

Type locality. - In the original description of Palinurus Japonicus no accurate locality is given by Von Siebold, so that the type locality is "Japo- 
nia". Von Siebold was stationed as a physician at the Dutch trading post of Decima near Nagasaki (he arrived there I I August I823) and was not allowed to leave the Nagasaki area until I 5 February 1826 , when he was permitted to join a state visit of the Dutch of ficials of the trading post to Kioto and Tokio (or Yeddo as it was named at that time). It seems logical therefore that the spiny lobster which Von Siebold described in 1824 came from the Nagasaki area, particularly as Von Siebold (I897, 1: 48) himself stated: "Zum Sammeln der Seetiere bot der Hafen von Nagasaki eine Gelegenheit, wie man sie kaum besser wünschen kann. Was sich nur immer an Fischen, Krabben u.dgl. auf den Fischmärkten vorfand, wurde Gegenstand meiner Beobachtung und der Untersuchung meiner wissbegierigen Schüler." Though Von Siebold did obtain material from other regions of Japan through his Japanese friends and pupils, it seems best to restrict the type locality of Panulirus japonicus here to Nagasaki.

Status of the name. - Palinurus japonicus Von Siebold, 1824, is the type species of the genus Panulirus White, 1847. The specific name japonicus Von Siebold, 1824, as published in the combination Palinurus japonicus, was placed as name no. 1496 on the Official List of Specific Names in Zoology in Opinion 507 of the International Commission on Zoological Nomenclature (see Hemming, I958).

Japanese name. - Kubo (1954) gave the official Japanese name of the species as Ise-ebi. Von Siebold (1824) already mentioned this name, which he spelled Ice-ebi. De Haan (I84I) mentioned the vernacular names Jebi and Iseno Kai rô. In Bürger's manuscript and on some labels of the material in the Leiden Museum the name Ebigane is found. Kikuti (1937) showed that the name No-ebi is used for old specimens of this species.

Remarks. - The original description of the species is extremely short, it runs as follows: "P. Japonicus, fronte bicorni, cornubus compressis integris, exemplarium maximorum longitudo pedum duorum et semis (c. antennis)". This description is entirely insufficient and fits any species of Panulirus. Fortunately De Haan ( $184 \mathrm{I}, \mathrm{r} 844$ ) gave a most satisfactory description and beautiful illustrations of Von Siebold's type material, while furthermore this type material is still extant. No doubt exists therefore about the identity of the species, which is the most common spiny lobster of Japan and forms the subject of an intensive fishery there. The best descriptions of the species apart from that by De Haan (I84I) are those by Gruvel (I9II) and by Kubo (1954).

Many non-taxonomic papers have been published on this species. These papers are mostly in the field of life history and propagation (Ortmann, I89I; Hattori \& Oisi, I899, I901; Bouvier, I905, I9r3; Calman, I909; 
Balss, I914; Terao, I915, I919, 1929; Nakazawa, I9I7; Kinoshita, I933, 1934, I934a; Kikuti, 1937; Nakamura, I937; Ohshima, 1942, 1948; Ino, I947, 1950; Okada, Kubo \& Takagi, I947; Okada \& Kubo, 1948, I950; Kubo, I950; Shiino, I950; Harada, I957, I959; Yamaji, 1959), ecology and biology (Kinoshita, I93 I, I931a, I932; Ohshima, I935, 1941; Kikuti, I939; Takayama, I939; Nakamura, I940; Okada \& Kubo, 1946; Kubo \& Hattori, I947; Harada, I957; Kubo, I961, 1962), physiology (Konishi, I955; Matsui, 1955, 1955a, I957; Matsui \& Shibuya, 1958), chromosomes (Niiyama, 1936, 1936a, I959), abnormalities (Yosii, I93 I, I933), and fishery (Kubo, I939, I940, 1953; Chace \& Dumont, I949; York, I949; Popovici \& Angelescu, 1954; Kubo \& Nonaka, 1955; F. G. W. Smith, 1958).

The dry male in the collection of the British Museum probably is the specimen listed by White (1847: 69) as Panulirus Japonicus under " $a$. Japan. From the Leyden collection." It is therefore a possible paralectotype.

Panulirus marginatus (Quoy \& Gaimard, 1825) (text-fig. rb; pl. 2)

Palinurus marginatus Quoy \& Gaimard, I825: 537, pl. 81 ; H. Milne Edwards, ı837: 30I ; Gruvel, I911: 28, 29; De Man, 1916: 34; Holthuis, I946: 125.

Palynurus marginatus Audouin, 1831 : 112.

Palniurus marginatus Audouin, 183I : pl. 65.

Langouste bordée Lucas, I836: 345, pl. 292 fig. 7.

Palinurus guttatus p.p. Pfeffer, 1881: 30, 33.

Palinurus japonicus Schauinsland, I899: I7, 59; Lenz, I901 : 440.

Panulirus japonicus Rathbun, I906: 897, pl. 5; p.p. Gruvel, I9I I : 28; p.p. Pesta, I9I5 : 10; Edmondson, 1925: 18; Edmondson, 1946: 257; Scheer \& Scheer, 1949: 9; Ball, 1950: 283; Leone, 1950: 123; Scheer \& Scheer, 1951: 198; Scheer, Schwabe \& Scheer, 1952: 328; Schwabe, Scheer \& Scheer, I952: 310, fig. I-4; Wiersma \& Ripley, 1952 : 395, 396; p.p. F. G. W. Smith, I958: 8.

Panulirus marginatus Rathbun, 1906: 897; Edmondson, 1946: 257.

Panulirus japonocum Galtsoff, I933: I7.

Panulirus japonicus marginatus Chace \& Dumont, 1949: 8.

non Panulirus marginatus R. O. Smith, 1948: 5, 52, 97, fig. 27.

Material examined.

Hawaiian Islands; donated by Hawaiian Government; 1883 International Fisheries Exhibition. - I ô $\mathrm{cl}$. $102 \mathrm{~mm}$ (BM no. 83.22).

Hawaiian Islands. - I juvenile cl. $20 \mathrm{~mm}$ (BM no. 59-79).

Oahu, Hawaiian Islands; 25 November 1960; T. Richert. - I ô cl. 66.I mm (WAM no. $166-62$ ).

Oahu; 30 February 196I; T. Richert. - I $\&$ cl. 5I.3 mm (WAM no. I67-62).

Honolulu, Oahu. - I 8 cl. $15 \mathrm{~mm}$ (USNM no. 25399).

Honolulu market, Oahu; 15 August 1902; "Albatross" Expedition. - I ô cl. $55 \mathrm{~mm}$, I juvenile $\mathrm{cl} .20 \mathrm{~mm}$ (USNM no. 30270).

Honolulu, Oahu; 26 July 1902; "Albatross" Expedition. - I ô cl. $60 \mathrm{~mm}$ (USNM no. $3027 \mathrm{I})$.

Honolulu, Oahu; 15 October 1962; T. Richert. - I $\&$ cl. $79 \mathrm{~mm}$ (WAM no. 35-63).

Near Waimea Bay, Oahu; 3 I August I947; F. M. Bayer. - I6 juveniles cl. I6-29 mm (USNM no. I05640, II specimens; RMNH no. D. 14508, 5 specimens). 
N.E. coast of Maui, Hawaiian Islands; $69-78$ fathoms; "Albatross" Expedition Station 4073. - I ô cl. $105 \mathrm{~mm}$ (USNM no. 30272).

Description. - The transverse groove of abdominal somite II may show a slight anteriorly directed median notch, in the following somites the transverse groove is practically straight. The transverse grooves of abdominal somites II to V curve gradually forward and then downward at their ends and join the pleural groove. The triangular plate $D$ of somite $I$ is entire, without any incision or groove. The anterior margin of the pleuron of somite II bears 2 or 3 distinct teeth, even in the largest specimens; this margin is convex. Apart from the hairs along the posterior margin of the somites and those along the transverse groove, the upper surface of the somites is entirely naked.

The antennular plate bears a pair of strong anterior spines, behind which there are two diverging rows of a number ( 7 to I I) spinules; three or four pairs of these spinules may be half as strong as the anterior spines.

The thoracic sternum in the male has in the median region of the posterior margin a pair of distinct posteriorly directed spines; one or two pairs of subsidiary spines may be present here. In the immature female there are two very tiny teeth, the adult female has two small but distinct teeth.

The pleopod of the second abdominal somite of the male possesses only a large foliaceous exopod, the endopod is absent.

Colour. - The carapace is pale purplish often marbled with whitish; some of the spines are white, others purple or purple with a white tip. Sometimes the carapace is pale bluish or greenish behind and pink before the cervical groove. The supraorbital horns are uniformly dark purplish with a whitish tip. A large white spot is present on the outer surface of the base of the horns. The abdomen is purple with transverse yellow bands along the posterior margin and over the transverse groove of each somite. The legs and antennular peduncles are almost uniformly purplish. White spots usually are present on the upper and lower part of the distal end of the outer surface of the merus, and also in its basal part. The carpus and propodus may show a whitish distal spot on the outer surface. In rare cases there is a faint indication of a white line on the outer surface of the segments of the pereiopods. The antennal peduncle is pale purplish or pink with the spines darker. The tail fan has the basal part purplish with some pale spots, the middle zone is bright yellow, the distal zone red. A pale spot is present just behind the articulation of the abdominal somites, on the top of plate $D$, in the dorso-median part of the first abdominal somite, and in the posteromedian part of the sixth abdominal somite.

In the material of the Western Australian Museum the male (WAM no. 
166-62) and the largest female (WAM no. 35-63) have the pale bands across the posterior margin of abdominal somites I to III broken up into a close series of spots; the remaining somites have the usual pattern of uniform transverse bands. As Rathbun (1906) remarked, the colour (but not the colour pattern) is somewhat variable, in some specimens the ground colour is violet with yellow, in others it is red; the spots, bands and spines are always yellow. In how far this difference in colour is also found in the living animals or is only due to a different action of the preservative is unknown to us.

Coloured figures of the species have been published by Quoy \& Gaimard ( 1825 ) and Rathbun (1906).

Distribution. - This species so far is only known from the Hawaiian Archipelago. The records in the literature are: Hawaiian Islands (Quoy \& Gaimard, I825; Pfeffer, I88I; Gruvel, I9I I; Edmondson, 1946; Chace \& Dumont, I949; Scheer \& Scheer, I949, I95I; Ball, I950; Scheer, Schwabe \& Scheer, I952; Schwabe, Scheer \& Scheer, 1952; Wiersma \& Ripley, 1952), Pearl and Hermes Reef, about $27^{\circ} 50^{\prime} \mathrm{N} 175^{\circ} 50^{\prime} \mathrm{W}$ (Galtsoff, 1933), Laysan (Schauinsland, I899; Lenz, I901; Edmondson, 1925), Honolulu, Oahu (Rathbun, I906; Pesta, 1915; Leone, 1950; F. G. W. Smith, 1958), north coast of Maui (Rathbun, I906). The species inhabits rocky crevices in shallow water. Galtsoff (I933) reported it from "under old coral rocks and in other well-protected places"; on the other hand it has also been reported (Rathbun, 1906) from a depth between 69 and 78 fathoms. Schauinsland (1899: 17) described how the species is fished at night at Laysan: "Zur Nachtzeit kann man mit Hilfe von Laternenlicht schöne, grosse Langusten aus ihren Verstecken unter überhängenden Felsen hervorlocken und mit einer Harpune erbeuten". The spiny lobsters from Palau, the Marianas, Carolines and Marshall Islands which R. O. Smith (1948) brought to Panulirus marginatus certainly do not belong to that species; the specimens shown in Smith's fig. 27 prove to be Panulirus versicolor (Latreille) and P. penicillatus (Olivier).

Type locality. - "Iles Sandwich" (= Hawaiian Islands).

Remarks. - The original description of Palinurus marginatus by Quoy \& Gaimard is very short and gives very few morphological details; it is mostly concerned with the colour of the species. This description is cited in full by Rathbun (I906). In view of the poor attention given to detail in this clescription, the species has been considered a species dubia by most workers. Many of the authors who tried to identify the species with any of the forms known to them were usually led astray by Quoy \& Gaimard's figure, where two pairs of spines are shown on the antennular plate (nothing is said about 
this feature in the description). H. Milne Edwards ( 1837 ) ranged the species among those that he could not place, and like Rathbun (I906), thought it related to $P$. homarus (L.), evidently on account of the spinulation of the antennular plate and the presence of uninterrupted grooves on the abdominal somites. Gruvel (I9I I) and Holthuis (I946) were more inclined to identify it with $P$. japonicus, while De Man (1916) gave no definite opinion. The peculiar colour pattern shown in Quoy \& Gaimard's plate and the locality of their material (Sandwich Islands = Hawaiian Islands), leave not the least doubt that what those authors had before them was the Hawaiian species which in recent literature is generally referred to as Panulirus japonicus. The fact that the small additional spinules on the antennular plate often are rather distinct in the present species may have caused the artist of Quoy \& Gaimard's plate to show the type of $P$. marginatus with 4 instead of with 2 large spines on the antennular plate.

The species is rather common in the Hawaiian Islands where it is sold for food on the local markets. At several occasions it has been used for physiological and serological investigations (Scheer \& Scheer, 1949, I95 I; Leone, I950; Scheer, Schwabe \& Scheer, I952; Schwabe, Scheer \& Scheer, I952; Wiersma \& Ripley, I952).

Panulirus pascuensis Reed, I954 (text-fig. Ic; pl. 3)

Palinurus frontalis p.p. Bürger, 1902: 707; p.p. Bürger, 1904: 7 .

Panulirus pascuensis Reed, I954: I3I, I36, fig. I-9; Holthuis \& Villalobos, I962: 252.

Material examined.

Easter Island, Chile, south-eastern Pacific; I934-1935; "Mercator" Expedition. - I \& cl. $8 \mathrm{r} \mathrm{mm}$ (ISNB).

Easter Island; 2I December I904. - I $q$ cl. $75 \mathrm{~mm}$ (USNM no. I05650).

Easter Island; received I2 February 1954; E. P. Reed. $-2 q \mathrm{cl} .80$ and $95 \mathrm{~mm}$ (USNM no. 9625I; RMNH no. D. I4504).

Easter Island; 1960 ; E. P. Reed. -2 o cl. 81.5 and $82.0 \mathrm{~mm}$ both with spermatophores (WAM no. I65-62).

Cook Bay, Easter Island; 29 December I934; "Mercator" Expedition. - I f cl. 95 mm with spermatophore (ISNB).

Pitcairn Island, South Pacific; May 1963; Melville Christian; don. R. B. Pike. - I of cl. $98 \mathrm{~mm}$, I $\%$ cl. $80 \mathrm{~mm}$ (RMNH no. D. 20367).

Pitcairn Island; December I963; Fletcher Christian; don. R. B. Pike. - I ô cl. 76 mm, I ovig. \& cl. $63 \mathrm{~mm}$ (RMNH no. D. 20368).

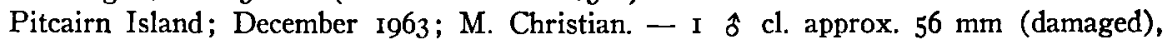
I ovig. o cl. $56.3 \mathrm{~mm}$ (AM no. P. I4650 and P. I465I).

Description. - The transverse grooves of the abdominal somites II to IV show a distinct and deep anteriorly directed median notch; in the female from Cook Bay the transverse grooves of somites IV and V are even slightly interrupted in the middle. The transverse groove of somite $\mathrm{V}$ is straight or 
practically straight. The transverse groove of somite II curves gradually forwards at its lateral end, but stops before reaching the pleural groove. The pleural groove sends out a short posteriorly directed branch at a short distance below the end of the transverse groove. In the somites III and IV the transverse groove joins the pleural groove. The triangular plate D of somite $I$ is entire, without incision or groove. The anterior margin of the pleuron of somite II bears no teeth, it is straight or slightly concave proximally, slightly convex distally. Some scattered short stiff hairs are present on the antero-lateral region of the second abdominal somite, there are no other pubescent areas on the abdominal somites, apart from the posteriorly directed fringe of setae along the posterior margin of the somites and along the transverse grooves.

The antennular plate bears the usual two large anterior spines, behind these there are two distinct rows of 2 to 5 very small spinules.

The thoracic sternum in the male ends in two distinct submedian teeth which are placed side by side in the middle of the posterior margin. In the female these teeth are small or absent.

The pleopods of the second abdominal somite in the male possess a large foliaceous exopod, but no endopod.

Colour. - The carapace in our preserved specimens is dark red, blue, or purple with a white lateral line and scattered pale spots. Some of the spines are white or have white tops. A white spot is present at the base of the rostral horns. The horns are red or purple with a small white top; some small white spots may be visible on the inner surface. One or two oblique white streaks are visible in the anterolateral region of the carapace. One or more white spots, sometimes forming a continuous white streak, are placed in the lateral part of the cervical groove. A row of rather large white spots is usually visible below the lateral white line. White spots are also present on the lateral and posterior margins of the carapace and the anterior part of the first abdominal somite. The anterior margin of the following somites shows a row of pale spots which are rather large and irregular in shape. Narrow white bands extend along the posterior margins of the abdominal somites and broader ones over the transverse grooves. On the pleura the latter band usually is discontinuous and visible as two large white spots, the proximal being as a rule shorter than the distal. A large white spot is present on the top of plate D and such spots are also found at and just behind the articulations of the abdominal somites. The sixth abdominal somite shows a posteromedian white spot. The calcified part of the telson is dark red, blue, or purple with large whitish spots; the membranaceous part is bluish or yellowish with a red or blue band followed by 
a yellowish line along the outer and posterior margins. The antennular peduncle is blue, red or purple dorsally and whitish ventrally with a white spot near the articulations. The flagella are blue, red or purple with a few narrow white bands. The antennal peduncle is blue, red or purple with some white spots, especially on the spines. The legs are red or purple with longitudinal narrow white bands similarly arranged as those of $P$. japonicus. In the males these bands are somewhat narrower than in the females. The pleopods are red or purple with a narrow whitish margin. Dr. R. B. Pike kindly placed at our disposal colour transparencies of fresh specimens from Pitcairn Island (Dec. I963). These showed the dorsal surface of the animals of a deep dark blue, almost black colour with the parts that are whitish in the preserved animals yellowish brown, only the bands on the antennular flagella are white. The lower surface of the thorax and the legs is yellowish brown mottled with whitish. The pleopods are dark blue with a narrow pale margin, and a white spot in the basal part.

Distribution. - The species is only known from Easter Island (Chile) and Pitcairn Island both in the South East Pacific. It was mentioned for the first time in the literature by Bürger (1902, I904) who, when dealing with Jasus frontalis (H. Milne Edwards) remarked that the species had also been reported to him as occurring on Easter Island. Bürger evidently did not examine any material himself. In I954 Reed gave an extensive and illustrated description of the species which he recognised as new and gave it the name Panulirus pascuensis.

Type locality. - "Isla de Pascua" (= Easter Island).

Panulirus cygnus George, I962 (text-fig. Id; pl. 4)

Panulirus penicillatus Dakin, I919: 174.

Panulirus longipes Anon., 1936: 16; Glauert, I936: x; Beck \& Sheard, 1949: 307; Sheard, I949: 7, 10; Sheard \& Dicks, I949: 352; York, I949: I, 4; Sheard, 1950: I0; Sheard, I954: I, fig. I-I2; George, I957: 476, fig. I-7; George, I958: 537, fig. I-3; Hodgkin, Marsh \& Smith, I959: 88; Ride \& Serventy, I961: 68; Sheard, I962: 1, fig. I-29.

Western Australian Crayfish, Taylor, I956: 95.

Panulirus n. sp. George \& Cawthorn, 1962: I.

Panulirus cygnus George, 1962: 100, text-fig. I-4, pl. I, 2.

Material examined.

Several localities in Western Australia between North West Cape (21 ${ }^{\circ} 45^{\prime} \mathrm{S}$ II $4^{\circ} 10^{\prime} \mathrm{E}$ ) and Point Peron $\left(32^{\circ} 16^{\prime} \mathrm{S} 115^{\circ} 4 \mathrm{I}^{\prime} \mathrm{E}\right)$; holo- and paratypes. $-42 \hat{\alpha} \mathrm{cl} .9$ to $120 \mathrm{~mm}$ (WAM).

Between Cape Naturaliste and Geraldton, Western Australia ; 20-100 fathoms; "Endeavour" Expedition, Sta. 2510 - I $\delta$ cl. II6 mm (AM no. E 2510).

Radar Reef and Strickland Bay, Rottnest Island, Western Australia; I7 February I959; R. W. George; paratypes. -4 i $\mathrm{cl}$. $66-\mathrm{II} 2 \mathrm{~mm}, \mathrm{I}$ \& $\mathrm{cl} .66 \mathrm{~mm}$ (RMNH no. D. I3107). 
Beagle Island, Western Australia; 33 fathoms; in crayfish pot; March-April I959; W. W. Poole. -4 specimens (AM no. P. 13499).

Description. - The transverse grooves of abdominal somites II to IV have the anterior margin broadly and shallowly indented in the middle. The groove of somite $\mathrm{V}$ is practically straight. At their lateral ends all the transverse grooves are curved slightly forward and downward and join the pleural grooves. In adults, the triangular plate $\mathrm{D}$ of somite $\mathrm{I}$ is completely bisected in a vertical direction by a hairy groove. The anterior margin of the pleuron of somite II shows no spinules; it is straight or slightly concave in the median part. In adults, each of the abdominal somites shows a distinct transverse pubescent band which extends over the entire breadth of the posterior half of the segment; this pubescence is formed by a dense field of short stiff hairs.

The antennular plate bears two strong anterior spines behind which there are two diverging rows of two, three or four distinct spinules; the largest of these spinules may be almost half as long as the anterior spines; some minute scattered additional spinules may also be observed on the plate.

The thoracic sternum in the male (both juvenile and adult) ends in two distinct submedian teeth which are placed close together; in the females these teeth are small in the juvenile or entirely absent in the adult.

The pleopods of the second abdominal somite of the male possess a large foliaceous exopod, but no endopod.

Colour. - The general colour of the body varies between pink and dark brownish red. The carapace is rather uniform in colour and possesses a distinct white lateral streak. The supra-orbital horns are rather uniform red with a narrow pale ring just below the horny tip. The abdomen is rather uniform reddish brown, with small pale dots, often arranged in more or less distinct transverse rows. These spots, in preserved specimens, may be indistinct or wanting. The usual large white spot behind the articulations of the abdominal somites and the one on the top of plate $D$ are also present. The tips of the pleura are white, and a white spot is present in the middle of the pleura of somites II to V just behind the end of the transverse groove; this white spot is most distinct in somite II, becoming less conspicuous in the following somites. The legs are of the same colour as the body or more purplish. The colour is rather uniform, but traces of longitudinal pale streaks can be seen in some specimens; where visible, these streaks do resemble those of $P$. japonicus as far as their position is concerned.

Distribution. - - The species is only known from Western Australia between $2 \mathrm{I}^{\circ} 45^{\prime} \mathrm{S}$ and $32^{\circ} 30^{\prime} \mathrm{S}$.

Type locality. - Radar Reef, Rottnest Island, Western Australia. 
Remarks. - Various aspects of the biology, morphological variation and economics of this commercially important species have been extensively dealt with by Sheard, I949, I954, I962, Taylor, I956 and George, 1957, I958, and 1962.

Common name. - In Western Australia, it is known as the "Western Australian crayfish", the "red crayfish" or the "white crayfish" when caught during a limited but commercially important period in November (see George, 1958). It is exported to the U.S.A. as "frozen rocklobster tails".

Panulirus longipes (A. Milne Edwards, I868) (text-fig. Ie; pl. 5)

Palinurus longipes A. Milne Edwards, 1868: 87, pl. 21 ; Richters, 1880: 16r.

Palinurus femoristriga Von Martens, I872: 125; Pfeffer, I88I : 35.

Palinurus guttatus Hoffmann, 1874: 42; Whitelegge, 1897: 146; Anon., 1899: 518.

Palinurus (Panulirus) longipes Miers, 1880 : 379.

Palinurus longitarsus Lenz \& Richters, I88ז : 426.

Senex femoristriga Ortmann, I891: 23.

Panulirus bispinosus Borradaile, I899: 418; De Man, I916: 33; Holthuis, 1946: I13.

Panulirus longipes Calman, 1909: 706; Kubo, 1954: 99, text-fig. 2, 3, pl. 3; Utinomi, 1956: 61, pl. 30 fig. 2; Rapson, 1962: 2.

Panulirus Japonicus p.p. Gruvel, I911: 28, pl. 5 fig. 3 (Panulirus japonicus, variété indo-africaine on: 56).

Panulirus japonicus Gruvel, 1914: 715, fig. 5; Gilchrist, 19I8: 5I ; McNeill, I929: I48; Von Bonde \& Marchand, 1935: 7 ; p.p. Holthuis, 1946: 123; p.p. Chace \& Dumont, 1949: 4, I0; Barnard, 1950: 550, fig. I02 f ; p.p. Popovici \& Angelescu, 1954: 508; Charbonnier \& Crosnier, 1961: 1; De Bruin, 1962: 12, fig. 5.

Panulirus japonicus longipes De Man, 1916: 33; Monod \& Petit, 1929: 273, fig. I.

Material examined.

Zanzibar; D. Kirk. - I of cl. $76 \mathrm{~mm}$, I o cl. $75 \mathrm{~mm}$ (BM no. I $8-32$ ).

Zanzibar; Dr. Robertson. - I ô cl. $98 \mathrm{~mm}$ (BM; dry).

Zanzibar; 21 May 1960; from market; A. J. Bruce. - I ô cl. $75 \mathrm{~mm}$, I $\$ \mathrm{cl} .87 \mathrm{~mm}$ (WAM no. 130-62).

East Africa; L.S.B. Leakey. - I 8 cl. $82 \mathrm{~mm}$ (BM no. I948.3.12.6).

Nosi Bé, Madagascar; December 1963-January 1964; J. H. Stock. - 3 ô cl. 44-55 mm, I ovig. \& cl. $57 \mathrm{~mm}$ (ZMA).

? Western Indian Ocean; H. Rawson. - I ovig. $\$$ cl. 89 mm (BM).

Seychelles; R. P. Dupont. -2 o cl. 72 and ror mm, I ovig. $\$$ cl. $72 \mathrm{~mm}$ (BM no. I93I.5.29.2).

Mauritius; M. E. Guérin coll. no. 279; don. T. B. Wilson. - I juv. cl. 9 mm (ANSP no. 343 ; preserved dry).

Mauritius. - I \& cl. $54 \mathrm{~mm}$ (BM; dry specimen).

Ceylon; G. H. P. De Bruin; received July I963. - I ô $\mathrm{cl} .56 \mathrm{~mm}$, I ovig. $\$$ cl. 50 mm (RMNH no. D. 18691).

Christmas Island; C. W. Andrews. - I juv. cl. $8 \mathrm{~mm}$ (BM no. 1909.5.19.253).

Malaysia; E. Gerrard. - I + cl. 85 mm (BM no. 8o-6).

Sabang, N. Sumatra; May 1928; J. A. van de Wetering de Rooij. - I juv. cl. 17 mm (ZMA no. IOI.821).

Amboina, Moluccas; i867; D. S. Hoedt. - I $q$ cl. $77 \mathrm{~mm}$ (RMNH no. D. 1430).

Banda, Moluccas; May I92I; E. van der Velde. - I ovig. $\$$ cl. $59 \mathrm{~mm}$ (ZMA no. IOI.820). 
Moluccas. - I $\delta$ cl. $93 \mathrm{~mm}$ (ZMA; preserved dry).

Moluccas; G. J. L. van der Hucht. - I $\$$ cl. $90 \mathrm{~mm}$ (ZMA; preserved dry).

Koki, 4 miles E. of Port Moresby, Papua; market; February I96I ; A. M. Rapson. I ovig. $\&$ cl. $82 \mathrm{~mm}$ (DFPM).

Sorido, Biak Island, West New Guinea; reef near village; 4 February I955; L. B. Holthuis no. 695. - I 9 cl. $69 \mathrm{~mm}$ (RMNH no. D. I7447).

San Miguel, Linapacan, Palawan, Philippines; caught by "chonchorro" method, using a net and an octopus; October 1949; A. Canonizado. - I $\hat{o}$ cl. $68 \mathrm{~mm}$ (USNM no. 90583).

Zamboanga City, Mindanao, Philippines; collected with local tarpon gear; 30 March 1949; A. Canonizado. - I fo cl. $93 \mathrm{~mm}$ (USNM no. 90580).

Taihoku, Formosa; M. Ohshima. - I 8 cl. 86 mm (USNM no. 55440).

Nafa, Okinawa, Ryukyu Islands; Igo6; "Albatross" Expedition. - I $\$$ i cl. $45 \mathrm{~mm}$ (USNM no. I05675).

Japan; 1823-1829; P. F. von Siebold; paralectotype of Palinurus japonicus Von Siebold. - I \& cl. $129 \mathrm{~mm}$ (RMNH no. D. 20387, preserved dry).

Japan. - I \& cl. $140 \mathrm{~mm}$ (USNM no. I05728, preserved dry).

Near Seto, Sirahama, Wakayama-ken, Japan; gill-nets; 23 April I961; I. Gordon and E. Harada. - I o cl. $5 \mathrm{I} \mathrm{mm} \mathrm{(BM} \mathrm{no.} \mathrm{I96I-II-I3-24I).}$

Seto; shallow water; March I96I; E. Harada. - I of cl. 64.2 mm (WAM no. 128-62), I $\&$ cl. $67.5 \mathrm{~mm}$ (WAM no. I64-62).

Heron Island, Queensland; May I96I; R. Manning - I $q$ cl. $68 \mathrm{~mm}$ (WAM no. 127-62).

Heron Island; in coral reef pool, $1.25 \mathrm{~m}$ deep; May I96I; R. W. George. -2 \% cl. 92 and $100 \mathrm{~mm}$ (WAM no. 129-62).

Ballina, Queensland; 65 fm.; June 1959; A. A. Racek. - I 9 cl. I Io mm (WAM no. I3I-62).

Northern New South Wales. - I 9 cl. $118 \mathrm{~mm}$ (AM).

Evans Head, New South Wales; 29 January 1935; R. Paddon. - I \& cl. IIo mm (QM no. W. 596).

Evans Head; in crayfish pot; December 1926; N. S. W. State Fisheries Dept. - I $q$ cl. $123 \mathrm{~mm}$ (AM no. P. 8747).

Evans Head; in crayfish pot; May 1955; N. S. W. State Fisheries Dept. - I $q$ cl. $109 \mathrm{~mm}$ (AM no. 10169).

Stockton Bight, New South Wales; May 1955; A. A. Racek. - I of cl. I Io mm (AM no. 13025).

New Caledonia; I934; A. M. Patch. - I $\hat{\text { o }} \mathrm{cl} .83 \mathrm{~mm}$ (USNM no. I05676).

Aneiteum, New Hebrides. -2 \& cl. 72 and $73 \mathrm{~mm}$ (BM; preserved dry).

Vitilevu, Fiji; on coral reef; 9 September I96r; R. Pahl. - I ovigerous $\$$ cl. $47.9 \mathrm{~mm}$ (WAM no. 163-62).

Description. - The transverse grooves of abdominal somites II to IV as a rule have the anterior median notch very indistinct and not interrupting the groove; in some specimens it is hardiy noticeable, in others it is more distinct and may interrupt the groove in the midline (e.g., of $6 \delta$ and ro $q$, cl. $49-80 \mathrm{~mm}$, examined in the Fisheries Department, Ceylon, by George, $2 \delta$ and $7 q$ had all grooves uninterrupted, $2 \delta$ and $2 q$ had only the groove on segment IV interrupted and $2 \delta \hat{\delta}$ and $\mathrm{I} q$ had only the grooves on segments III and IV interrupted). The transverse groove of somite $\mathrm{V}$ is straight. The lateral ends of the transverse groove of somites II to $\mathrm{V}$ are 
curved forward and then downard and join the pleural grooves. The triangular plate D of somite I is variable; in some specimens it is entire, in others it may show an incision in the external margin, which may become so deep as to completely bisect the plate (this variation is discussed later). The anterior margin of the pleuron of somite II is entire or shows a few inconspicuous tubercles. Apart from the hairs along the transverse groove and the posterior margin of the abdominal somites, the dorsal surface of the somites is naked or with a few scattered short stiff hairs, which, however, never from distinct pubescent areas.

The antennular plate bears two strong anterior spines. Behind these the plate shows two posteriorly diverging rows of one to six distinct spinules; two or three is the more common number of spines. All the eastern Australian specimens have three to six spines in each row.

In both the males and the females the thoracic sternum ends posteriorly in two distinct submedian teeth, which are placed close together.

The pleopods of the second abdominal somite of the male possess no endopod, the exopod is large and foliaceous.

Colour. - The ground colour of the carapace is brownish or purplish and is ornamented with pale spots and stripes; the central area is darker than the anterior, lateral and posterior areas and is marked of $f$ from the posterior region by a bow-shaped pale mark. A row of pale spots which sometimes form a continuous pale line is placed in the cervical groove. Anterolaterally, there is a short longitudinal pale stripe leading back from the post-antennal spine towards the cervical groove. Laterally there is another distinct pale line. Many of the spines are white below the tip and there are often white spots or marks all over the carapace, sometimes these are restricted to the posterior margin. The supra-orbital horns are brown or purple with a few transverse or oblique narrow white bands, which are often widened dorsally and are sometimes reduced to spots on the dorsal and ventral margins of the horns. The entire abdomen is spotted with rather large white dots, the ones just behind the articulations of the abdominal somites being much larger than the rest. A large white spot is also present on the top of plate D. The antennular peduncle is brown or purple with white spots at the articulations. The flagella are brown or purple sometimes banded with white. The antennal peduncle is of a pale brown or purple colour with the spines darker; the flagella are brown or purple, or white.

The legs are purple, spotted or streaked with white. In the colour pattern of the legs two forms can be distinguished, "spotted" and "striped". In the spotted form five bright white spots are very obvious on the dorsal surface of the legs. These spots are situated at the distal regions of the propodus, 
carpus and merus with the two remaining spots in the central and proximal regions of the merus. Below or on the outside of these dorsal spots on the merus are three similar white spots. Between the white spots are often darker longitudinal lines which usually do not touch the spots; these lines may be orange or brownish. Sometimes additional smaller white spots are placed between the larger. In some specimens only the large spots are obvious, the lines being very indistinct; usually the pattern of discrete spots separated by longitudinal lines of a darker colour is apparent.

In the striped form, there are several thin longitudinal lines of uniform colour. The dorsal surfaces of the merus, carpus and propodus bear an almost continuous single line, sometimes less apparent on the propodus. There are two such lines on the lateral and one on the ventral surface of the merus, and one or two such lines on the lateral surface of the carpus and propodus. The distal region of the dorsal and ventral line on the merus may expand around the base of the anterodorsal spine and this expanded region may be broken off from the main line; further, the central region of the dorsal meral line (particularly in the fifth leg) may expand and become similarly separated from the main line. However, the colour pattern on the legs of this form never shows the numerous distinct white spots clearly separated from lines of a different colour on all legs. Intermediate forms between the two extremes are found and will be discussed later.

Distribution. - The species has a very wide distribution in the Indo-West Pacific area, its range extends from East Africa to Japan and Polynesia. The records in the literature are: Zanzibar (A. Milne Edwards, I868), Delagoa Bay, Portuguese East Africa (Barnard, 1950), off Natal (Gilchrist, 1918; Von Bonde \& Marchand, I935; the correctness of these records is questioned by Barnard, I950), Madagascar (Lenz \& Richters, I88I; Monod \& Petit, I929), west, north-west and east coasts of Madagascar (Charbonnier \& Crosnier, I96I), north coast of Madagascar (Gruvel, I9I4), Nosy Bé, N.W. Madagascar (Monod \& Petit, I929), Anakao, S.W. Madagascar (Monod \& Petit, I929), Réunion (Gruvel, 191 I), St. Gilles, Réunion (Monod \& Petit, I929), Mauritius (A. Milne Edwards, I868; Hoffmann, I874; Miers, I880; Ortmann, I891), Port Louis, Mauritius (Monod \& Petit, I929), Ile aux Fouquets, Mauritius (Richters, I880), Ceylon (De Bruin, 1962), Indomalayan Seas (Miers, I880), Christmas Island (Calman, r909), Sabang, north Sumatra (Holthuis, I946), Amboina, Moluccas (Von Martens, I872; Holthuis, I946), Banda, Moluccas (Holthuis, I946), New Guinea (Pfeffer, I88I), south coast of Papua (Rapson, I962), Japan (Gruvel, I9I I; Holthuis, I946; Utinomi, I950), Kominato, Chiba Prefecture, Japan (Kubo, I954), 3 miles E. of Evans Head near Ballina, Richmond River, 
northern New South Wales, Australia (McNeill, 1929), Sandal Bay, Lifu, Loyalty Islands (Borradaile, I899), Aneiteum, New Hebrides (Miers, I880), Funafuti Atoll, Ellice Islands (Whitelegge, I897; Anon., I899), Tahiti (Ortmann, I89I). Of the five species of the japonicus-group the present is the one with the most extensive range, all the others have a very restricted distribution. As shown below it is possible that the species may have to be divided into an eastern and a western subspecies.

Type locality. - In the original description material of the species from two localities is mentioned: Zanzibar and Mauritius. As Milne Edwards's account clearly is based on the Zanzibar specimen, this specimen is now selected to be the lectotype of Palinurus longipes A. Milne Edwards, which automatically restricts the type locality to Zanzibar.

Habitat. - The only accounts of the habitat of the species are by Whitelegge (I897: 146) who stated that it "lives in burrows on the sandy portions of the lagoon, and is much used by the natives as food", and De Bruin (I962 : 19) who observed them living non-gregariously in reef and rocky areas and then stated that on moonlit nights they "may be taken in comparatively larger quantities than on dark nights, fair numbers being seen in the open even on full-moon nights".

Vernacular name. - Whitelegge ( $1897:$ 146) mentioned that the species is named "Oula" by the natives of Funafuti Atoll.

Remarks. - The present species differs from all others in the japonicusgroup not only by the brightly coloured and spotted carapace but also by the conspicuous colour pattern of the abdomen which consists of numerous rather large white dots uniformly distributed over the dorsal surface; there are no transverse bands of colour.

In two features Panulirus longipes shows a variability which is rather unusual in this group, viz., in the shape of plate $D$ and in the colour pattern of the legs. In some specimens plate D presents no groove at all and has the upper surface a perfect flat triangle. This shape is found in specimens from Zanzibar (WAM no. I30-62; the 3 specimens of BM), East Africa (BM no. I948.3.I2.6), Western Indian Ocean (BM), Seychelles (BM no. I931.5.29.2), Mauritius (BM), Malaysia (BM no. 80-6), Ceylon (RMNH no. D. I869I), Japan (WAM no. I64-62; RMNH no. D. 20387), Queensland (WAM no. I29-62), New Caledonia (USNM no. I05676), New Hebrides (BM). In another group the outer margin of the plate shows a short incision, viz., in specimens from Madagascar (ZMA), Banda (ZMA no. Iоr.820), New Guinea (DFPM; RMNH no. D. I7447), Japan (WAM no. I28-62; BM no. I961.Ir.I3.24I), Queensland (WAM no. 129-62), New South Wales (AM; QM no. W. 596; AM no. I3025), Fiji (WAM 
no. $163-62$ ). In the third group the plate is completely divided in two by a deep hairy groove, viz., in specimens from Amboina (RMNH no. D. I430), Palawan (USNM no. 90583), Mindanao (USNM no. 90580), Formosa (USNM no. 55440), Okinawa (USNM no. I05675), New South Wales (AM no. P. 8747; AM no. ror69). The presence of this groove seems not to be connected either with sex, age or locality, and therefore, unless other evidence is forthcoming, seems to be subject to individual variation only. The variation in the colour pattern of the legs has already been discussed in the paragraph "Colour". Of the specimens examined by us the following belong to the spotted form: the $3 \delta$ and $2 q$ from Zanzibar, the $\delta$ from East Africa, the $q$ from the Western Indian Ocean (BM), the $3 \hat{\delta}$ and $q$ from Madagascar (ZMA), the $2 \delta$ and $q$ from the Seychelles, the $q$ from Mauritius $(\mathrm{BM})$, the $\delta$ and $q$ from Ceylon, the $q$ from Malaysia, the $\delta$ from Palawan, and the $\delta$ from Formosa. Also to this form belongs a specimen from Mauritius, a colour photograph of which was given to us by Dr. E. P. Hodgkin. A. Milne Edwards (1868) in his figure of the type of Palinurus longipes does not show the colour pattern of the legs. A comparison of A. Milne Edward's figure with the photograph of Panulirus japonicus variété indo-africaine published by Gruvel (I9II) shows such a remarkable similarity between these two illustrations that it seems well possible that they represent the same specimen. In Gruvel's figure the legs of the specimen are shown to be of the spotted type, with spots in leg 5, and spots and intermediate lines in legs 3 and 4 (at least at the right side). Gruvel's photograph was republished by him in I9I4. The colour description of Madagascar specimens by Monod \& Petit (1929: 275) also shows that their material belongs to the spotted form: "Pattes brunes, avec filets orangés et taches blanches". Barnard's (I950: 55I) description "legs ... violaceous with yellowish-white longitudinal lines, and a few spots" is not very clear, but might pertain to the spotted form. The striped form is represented in our material by the following specimens: the female from Amboina, the female from Banda, the two dry specimens from the Moluccas (ZMA), the two females from New Guinea, the Japanese specimens in the Perth and Leiden Museums, and the specimens from Queensland, New South Wales, New Caledonia, the New Hebrides, and Fiji. To this form evidently belongs the type specimen of Palinurus femoristriga Von Martens as in the original description of that species Von Martens (I872: 127) stated: "Femoralglieder wie die Tarsalglieder mit Längsbändern"; this character is also very aptly expressed in the specific name femoristriga. Pfeffer ( $1881: 36$ ) stated of his New Guinea specimens "Die Beine sind violett gebändert". In his description of the Japanese specimen of $P$. longipes, Kubo (I954: IOO, IOI) 
remarked that the "thoracic legs ... have no blotches"; Kubo's specimen possibly is the same as the one figured by Utinomi (1956) and in which the legs indeed are striped. Miers ( 1880 : 380) described the colour of the pereiopods of his material (from Indomalayan Seas, Mauritius, and New Hebrides) as "marked with longitudinal lines of the same colour [pale yellow], which are sometimes broken into irregular spots or blotches". As shown by his material, which is still in the British Museum, his Mauritius and Indomalayan specimens belong to the spotted, the New Hebrides material to the striped form. Ortmann ( I89r: 24) stated "Beine gelb und blau länggestreift", but it is not clear whether this pertains to all of his material (from Mauritius and Tahiti) or only to part of it.

The two forms cannot be sharply separated, and intermediate forms occur. In Gruvel's (I9I I) photograph the dorsal margin of the merus of the left second pereiopod seems to have an uninterrupted white line, while the fifth legs are clearly spotted; at any rate it is far closer to the spotted than to the striped form. In the Zanzibar specimens in the British Museum the colour pattern of the legs is quite typically spotted, only the carpus of legs 2 to 4 shows a broad dorsal stripe, of which in leg 5 a distal spot is split off. In the Seto specimen the distal spot of the merus of leg I is not sharply set off from the line, but in the following legs both the distal and the proximal spot are distinct, while the central spot is only visible in leg 5, where it is not clearly set off from the line. The carpus in this specimen has an uninterrupted dorsal line, while that of the propodus is uninterrupted in legs I to 3 , interrupted in 4 , while the propodus of leg 5 shows only the distal spot and no line. The Malaysian specimen has both the merus and the carpus of leg I and 2 striped, those of legs 3 to 5 very distinctly spotted, the propodus of legs $I$ and 2 is indistinctly striped, those of legs 3 to 5 are spotted. The Seychelles specimens are typically spotted, only the propodus of legs I and 2 are striped. The Madagascar specimens (ZMA) have the propodi of all legs clearly striped; some spots are only visible in the proximal part of the ventral surface. Except in the right fourth leg of a male where the dorsal and lateral stripes are slightly interrupted at the base, all stripes are fully continuous. Another peculiarity of these Madagascar specimens is that apart from the usual white spots on the merus and carpus of the legs, there are additional spots placed in between the normal ones.

In some striped specimens the dorsal line is interrupted slightly before the end, so that a more or less distinct distal white spot is formed (e.g., in Utinomi's figure). In the Amboina specimen of the Leiden Museum the dorsal white line of the merus of the pereiopods is twice interrupted slightly proximal of the middle and a spot is formed similar to the middle spot of 
the first form. Summarizing we may state that, basing ourselves on the colour pattern of the legs, two forms can be recognized in Panulirus longipes. The form which we named the spotted inhabits the western part of the range of the species (E. Africa, Madagascar, Mauritius, Seychelles to the Philippines, and Formosa) and could be given the name Panulirus longipes longipes (A. Milne Edwards). The second or striped form inhabits a more eastern area (Japan, the Moluccas, New Guinea, Eastern Australia to Polynesia); for it the very suitable name Panulirus longipes femoristriga (Von Martens) is available. A careful examination of more material (and especially of fresh material) is necessary to prove or disprove the validity of these two supposed subspecies.

Borradaile (1899) described a new species, Panulirus bispinosus, which is based on a juvenile specimen. Borradaile pointed to the close resemblance of his new species to $P$. femoristriga ( $=P$. longipes) and mentioned as differential characters the fact that the antennular plate in the new species bears no spinules additional to the pair of large anterior spines, and that the abdominal transverse grooves are interrupted in the middle. As these two differences in all probability are due to the fact that Borradaile's specimen is juvenile, we see no sufficient reason not to synonymize $P$. bispinosus with $P$. longipes.

The specimen from Christmas Island reported upon by Calman (1909) is present in the B.M. It is a very young stage of which little can be said. The antennal plate shows 2 spines and lacks spinules. The abdominal grooves are interrupted. There is no reason to doubt the correctness of the identification.

\section{SUMMARY}

Five separate species have previously been included under the name "Panulirus japonicus". Four of these species, $P$. japonicus from Japan, $P$. marginatus from Hawaii, $P$. pascuensis from the S.E. Pacific, and $P$. cygnus from W. Australia, have restricted distributions and form the basis for commercial fisheries. The fifth species $P$. longipes, is of little commercial importance and exhibits the strongest morphological variation of the japonicus group; an eastern striped-legged form and a western spotted-legged form probably represent subspecies of this widely distributed Indo-West Pacific species.

\section{Literature CITED}

AnoN., J899. Summary of the fauna of Funafuti. - Mem. Aust. Mus. 3: 513-535.

- 1936. The wrong name. - The West Australian Newspaper, in July I936: I6.

-, I954. Illustrated encyclopedia of the fauna of Japan (Exclusive of Insects), (revised edition) : I-4, I, 2, I, 2, I-IO, I-I898, I-I8, I-20, I-I08, I-89, text-fig. I-52I3, pl. I-I2.

Albert, F,, 1883. Ueber das Kaugerüst der Makruren : I-80, fig. I, 2.

-_, 1883a. Das Kaugerüst der Dekapoden. - Zeitschr. wiss. Zool. 39: 444-536, textfig. I, 2, pl. 29-3I. 
Audouin, V., I831. Crustacés. - Dictionnaire classique d'histoire naturelle 17: I12, pl. 63-65.

BALL, G. H., I950. Examination of Hawaiian marine crustaceans for gregarines. Pacific. Sci. 4: 283.

BALss, H., 19I4. Die Natantia und Reptantia. Ostasiatische Decapoden II. In: F. DofLEIN, Beiträge zur Naturgeschichte Ostasiens. - Abh. Bayer. Akad. Wis.. (suppl.) 2 (IO) : I-IOI, text-fig. I-50, pl. I.

Barnard, K. H., I950. Descriptive catalogue of South African Decapod Crustacea. Ann. S. Afr. Mus. 38: I-837, fig. I-I54.

Beck, A. B. \& K. Sheard, I949. The copper and nickel content of the blood of the Western Australian marine crayfish (Panulirus longipes Milne Edwards) and of seaweeds. - Aust. Journ. exp. Biol. med. Sci 27 : 307-312.

Bonde, C. von \& J. M. MARChAND, I935. The natural history and utilization of the Cape Crawfish, Kreef, or Spiny Lobster, Jasus (Palinurus) lalandii (Milne Edwards) Ortmann. - Fish Bull. Fish mar. biol. Surv. S. Afr. 1: I-55, pl. I-8, map I-9.

Borradaile, L. A., I899. On the Stomatopoda and Macrura brought by Dr Willey from the South Seas. In: A. WILley, Zoological results based on material from New Britain, New Guinea, Loyalty Islands and elsewhere, collected during the years I895, I896 and I897 4: 395-428, pl. 36-39.

Bouvier, E. L., I899. Sur une collection de Crustacés du Japon offerte au Muséum par M. Boucard. - Bull. Mus. Hist. nat. Paris 5: I73-176.

- I905. Palinurides et Eryonides recueillis dans l'Atlantique oriental pendant les campagnes de l'Hirondelle et de la Princesse-Alice. - Bull. Mus. océanogr. Monaco 28 : $1-7$.

- 19i3. Le stade "Natant" ou "Puerulus" des Palinuridés. - Trans. 2nd entom. Congr.: 78-89.

BürGER, O., Ig02. Ein Fall von lateralem Hermaphroditismus bei Palinurus frontalis M.-E. - Zeitschr. wiss. Zool. 71: 702-707, fig. I-4.

- - 1904. Un caso de hermafroditismo lateral en la Langosta de Juan Fernández (Palinurus Frontalis M.-E.). - An. Univ. Chile 113: 59I-599, 2 pls.

Calman, W. T., Ig09. On decapod Crustacea from Christmas Island, collected by Dr. C. W. Andrews, F.R.S., F.Z.S. - Proc. zool. Soc. Lond. 1909: 703-713, pl. 72.

- Igoga The genus Puerulus, Ortmann, and the postlarval development of the spiny lobsters (Palinuridae). - Ann. Mag. nat. Hist. (8) 3: 44I-446.

Chace, F. A. \& W. H. Dumont, I949. Spiny lobsters - identification world distribution, and U.S. trade. - Commerc. Fish. Rev. 11 (5) : I-I2, fig. I-7.

Charbonnier, D. \& A. Crosnier, ig6r. Quelques données sur la pêche de langouste à Madagascar. - Pêche marit. $994:$ I-3.

Chen, T. Y., I934. A preliminary report on the marine products of Amoy. - Nat. Sci. Bull. Univ. Amoy 1: I-zo.

DAKIN, W. J., 19I9. Introduction, general description of the coral islands forming the Houtman Abrolhos Group, the formation of the islands. The Percy Sladen Trust Expeditions to the Abrolhos Islands (Indian Ocean). Report I. - Journ. Linn. Soc. London, Zool. 34 : I27-180, text-fig. I-12, pl. I0-14.

De Bruin, G. H. P., 1962. Spiny lobsters of Ceylon. - Bull. Fish. Res. Sta. Ceylon 14: I-28, fig. I-IO.

DofleIN, F., Igoo. Weitere Mitteilungen über dekapode Crustaceen der $\mathbf{k}$. bayerischen Staatssammlungen. - S. B. Bayer. Akad. Wiss. 30: 125-145, fig. I-3.

—, I902. Ostasiatische Dekapoden. - Abh. Bayer. Akad. Wiss. 21 : 6r3-670, textfig. A-D, pl. I-6.

- I I I06. Ostasienfahrt. Erlebnisse und Beobachtungen eines Naturforschers in China, Japan und Ceylon: i-xiii, I-5II, textfigs., pls., 4 maps. 
- I I Ges. $16: 62-72$.

Edmondson, C. H., 1925. Crustacea. Marine zoology of tropical Central Pacific. (Tanager Expedition Publ. 1). - Bull. Bishop Mus. Honolulu 27: 3-62, pl. I-4.

-, 1946. Reef and shore fauna of Hawaii. - Spec. Publ. Bishop Mus. Honolulu 22: i-iii, I-38I, fig. I-223.

EsAKI, T., 1956. Support for Dr. Holthuis' proposal relating to the generic name "Panulirus" White, 1847 (Class Crustacea, order Decapoda). - Bull. zool. Nomencl. 12: 266

FISHERIES SOCIETY JAPAN, 1935. Illustration of Japanese aquatic plants and animals 2 : pl. 5I-IOO.

Galtsoff, P. S., 1933. Pearl and Hermes Reef, Hawaii, hydrographical and biological observations. - Bull. Bishop Mus. Honolulu $107:$ I-49, textfig. I-9, tab. I-6, pl. I-5.

George, R. W., 1957. Continuous crayfishing tests: Pelsart Group, Houtman Abrolhos, Western Australia, 1953. - Aust. Journ. mar. freshw. Res. 8: 476-490, fig. I-7, tab. $\mathbf{I}-4$.

- 1958. The status of the "White" crayfish in Western Australia. - Aust. Journ. mar. freshw. Res. 9: 537-545, fig. I-3, tab. I, 2.

-, 1962. Description of Panulirus cygnus sp. nov., the commercial crayfish (or spiny lobster) of Western Australia. - Journ. Roy. Soc. West. Aust. 45: Ioo-r1o, textfig. I-4, pl. I, 2 .

Grorge, R. W. \& P. CAWthorn, 1962. Investigations on the Phyllosoma larvae of the Western Australian crayfish. - Report to Western Fisheries Research Committee, Fisheries Department, Western Australia: I-9 (mimeographed).

Gilchrist, J. D. F., I9I8. The Cape Lobster and the Cape Crawfish or Spiny Lobster. - Mar. biol. Rep. S. Afr. 4: 44-53, 2 pls.

Glauert, L., 1936. Exhibit of three species of Panulirus occurring on the west coast of Australia. - Journ. Roy. Soc. West. Aust. 22: x.

Gordon, I., I953. On the Puerulus stage of some spiny lobsters (Palinuridae). - Bull. Brit. Mus. (Nat. Hist.) Zool. 2: I7-42, fig. I-9.

Gruver, A., I9I I. Contribution à l'étude générale systématique et économique des Palinuridae. Mission Gruvel sur la cỏte occidentale d'Afrique (I909-1910). Résultats scientifiques et économiques. - Ann. Inst. océanogr. Monaco 3 (4) : 5-56, textfig. I-22, pl. I-6.

—_, rgira. Contribution à l'étude systématique des Palinuridae. - C.R. Acad. Sci. Paris 152: I 350-r 352.

- - I914. Les Langoustes des côtes de Madagascar. Leur classification, leur exploitation. - Rév. gén. Sci. pure appl. 25: 7II-7I7, fig. I-5.

HaAn, W. de, I833-1850. Crustacea. In: P. F. de Siebold, Fauna Japonica sive descriptio animalium, quae in itinere per Japoniam, jussu et auspiciis superiorum, qui summum in India Batava Imperium tenent, suscepto, annis $1823-1830$ collegit, notis, observationibus et adumbrationibus illustravit: ix-xvi, i-xxxi, vii-xvii, I-244, pl. I-55, A-Q, 2.

Harada, E., 1957. Ecological observations on the Japanese Spiny Lobster, Panulirus japonicus (Von Siebold), in its larval and adult life. - Publ. Seto mar. biol. Lab. 6: 99-120, textfig. $1-6$, pl. 6,7 .

- 1959. Occurrence of the first stage Phyllosoma larva of Panulirus japonicus (von Siebold) in Tanabe Bay. A study on the productivity of Tanabe Bay (Part II). V. - Rec. oceanogr. Works Japan (spec. no.) 3: 57-60, fig. I.

Hattori, T. \& Y. Oisi, I899. On the rearing of Panulirus japonicus. I. - Journ. Imp. Fish. Inst. Tokyo 1 (2).

$-\&-$, IgoI. On the rearing of Panulirus japonicus. II. - Journ. Imp. Fish. Inst. Tokyo 2 (I). 
Heller, C., I865. Crustacea. Reise der österreichischen Fregatte Novara um die Erde in den Jahren 1857-58-59 unter den Befehlen des Commodors B. von WüllerstorfUrbair (Zool.) 2 (3): I-280, pl. I-25.

Hemming, A. F., 1958. Opinion 507. Use of the plenary powers to secure that the generic name Panulirus White, I 847 (Class Crustacea, Order Decapoda) shall be the oldest available name for the genus concerned - Opin. Decl. Int. Comm. zool. Nomencl. 18: 197-210.

Herkiots, J. A., I86r. Catalogue des Crustacés qui ont servi de base au système carcinologique de $\mathrm{M}$. W. de Haan, rédigé d'après la collection du Musée des Pays-Bas et les Crustacés de la Faune du Japon. Symbolae carcinologicae. I. - Tijdschr. Ent. 4: II6-I56.

Hodgkin, E. P., Marsh, L. \& Smith, G. G., 1959. The littoral environment of Rottnest Island. In: Hodgkiv, E. P. \& K. Sheard, Rottnest Island. The Rottnest Biological Station and recent scientific research. - Journ. Roy. Soc. West. Aust. 42: 85-88.

Hoffmann, C. K., 1874. Crustacés et Echinodermes de Madagascar et de l'île de la Réunion. In: F. P. L. Pollen \& D. C. VAN Dam, Recherches sur la faune de Madagascar et de ses dépendances 5 (2): I-58, pl. I-Io.

Holthuis, L. B., 1946. The Stenopodidae, Nephropsidae, Scyllaridae and Palinuridae. The Decapoda Macrura of the Snellius Expedition. I. Biological results of the Snellius Expedition. XIV. - Temminckia 7: I-I78, textfig. I, 2, pl. I-II.

-.. I956. Proposed use of the plenary powers to render the generic name "Panulirus" White, I847 (Class Crustacea, Order Decapoda) the oldest available name for the genus concerned and matters incidental thereto. - Bull. zool. Nomencl. 12: 55-59.

Holthuis, L. B. \& A. Villalobos, 1962. Panulirus gracilis Streets y Panulirus inflatus (Bouvier), dos especies de langosta (Crustacea, Decapoda) de la costa del Pacifico de America. - An. Inst. Biol. Univ. Mexico 32: 251-276, fig. I-I9, I map.

INo, T., I947. Number of eggs and spawning-periods of Ise-ebi (Panulirus japonicus De Haan). - Bull. Japan. Soc. sci. Fish. 13 (I) : 32, 33, fig. I.

- 1950. Observation on the spawning cycle of Ise-ebi, (Panulirus japonicus (v. Siebold)). - Bull. Japan. Soc. sci. Fish. 15: 725-727, fig. I, 2.

KIKUTI, T, 1937. The so-called "No-ebi" in Kôti Prefecture identical with older specimens of Panulirus japonicus. - Yôsyokukaisi (Journ. Soc. Piscic.) 7 (9).

- 1939. Natural habitat of male and female of Panulirus japonicus in Nagasaki Prefecture. - Suisankenkyûsi (Journ. Fish. Res.), 34 (7).

Kinoshita, T., I93I. Some ecological notes on Panulirus japonicus. - Suisankenkyûsi (Journ. Fish. Res.) $26: 231-236$.

-, I931a. Biological minimum size of Panulirus japonicus. - Rep. Fish. Exper. Sta. Wakayama Pref. 28.

- 1932. On the migration and growth of Panulirus japonicus. - Rep. Fish. Exper. Sta. Wakayama Pref. 30.

- I933. On the propagation of the spiny lobster, Panulirus japonicus (v. Siebold). - Bull. Jap. Soc. sci. Fish. 1: 247-240, fig. I.

-1 1934. On the artificial propagation of Panulirus japonicus. (de Haan) and some account of its larvae. - Proc. 5th Pacific Sci. Congr. 5 : 419I-4I93.

-, I934a. Studies on Puerulus of spiny lobster, Panulirus japonicus (v. Siebold), and its later metamorphosis. - Dobuts. Zasshi (= Zool. Mag.) Tokyo 46 : 39I-399, 2 pls.

Komat, T., K. Akatsuka \& J. Ikari, I927. The Seto Marine Biological Laboratory of the Kyoto Imperial University. Its equipment and activities, with remarks on the fauna and flora of the environs. - Mem. Coll. Sci. Kyoto Imp. Univ. (B) 3 (3) 28I-306, textfig. I-8, pl. I2.

Komai, T. \& J. Ikari, I929. The Seto Marine Biological Laboratory of the Kyoto Imperial University. Its equipment and activities, with remarks on the fauna and 
flora of the environs (A revised article). - Rec. oceanogr. Works Japan 1: II3129, pl. 27-35.

KonishI, J., I955. Retinal and optic nerve response of the compound eye of spiny lobster, Panulirus japonicus (v. Siebold). - Rep. Fac. Fish. pref. Univ. Mie 2: 138-144, fig. I-5.

Kuвo, I., 1938. Notes on the sexual dimorphism of the spiny lobster, Panulirus japonicus (v. Siebold), - Journ. Imp. Fish. Inst. Tokyo 33: IoI-I06, textfig. I-4, tab. I, 2, pl. I.

- 1939. Yearly catch of 20 prefectures. Statistical observation on the yield of Japanese Spiny Lobster, Panulirus japonicus (v. Siebold). I. - Bull. Japan. Soc. sci. Fish. 8: I38-140, fig. I, 2.

-, I940. Yearly catch in relation to precipitation. Statistical observation on the yield of the spiny lobster, Panulirus japonicus (v. Siebold). II. - Bull. Japan. Soc. sci. Fish. 8: 287-29I, fig. I, 2, tab. I-8.

- 1950. On two forms of Puerulus found in Japanese waters, with special reference to that of Panulirus versicola (Latr.). - Bull. Japan. Soc. sci. Fish. 16: 9I-98, fig. I-4, tab. I, 2.

- I I953. The best fishing time of the Japanese Spiny Lobster, Panulirus japonicus (V. Siebold). - Aquiculture, Japan, 1 (I) : 30-32, fig. A-D.

-, I954. On the palinurid lobsters. Systematic studies on the Japanese macrurous decapod Crustacea. 3. - Journ. Tokyo Univ. Fish. 41 (I) : 95-I05, textfig. I-3, pl. 3-6.

- 1956. A review of the biology and systematics of shrimps and prawns of Japan. Proc. Indo-Pacif. Fish. Counc. 6: 387-398, fig. I-8.

-, I960. Macrura. In: Y. K. OKadA \& T. UChDA, Encyclopaedia zoologica illustrated in colours 4: $98-\mathrm{II}_{3}$, pl. $49-56$.

- I I96r. Stomach volume of Japanese Spiny Lobster, Panulirus japonicus. - Bull. Japan. Soc. sci. Fish. 27 (12): 1063-1065, fig. I-3.

-, I962. On the bimodality found in the catch of Japanese Spiny Lobster, Panulirus Japonicus. - Bull. Japan. Soc. sci. Fish. 28 (3) : 322-325, fig. I-3.

Kubo, I. \& S. Hatrori, 1947. An analysis of tagging results of Panulirus japonicus (v. Siebold), with special reference to the rate of growth and ecdysis, - Bull. Japan. Soc. sci. Fish. 13 (3): 108-i 10.

Kubo, I. \& T. Nonaka, I955. Price of Panulirus japonicus and prosperity. - Rakusui January 1955: I7-20, figs. I, 2.

Lenz, H., I90I. Crustaceen. Ergebnisse einer Reise nach dem Pacific (Schauinsland I896-I897). - Zool. Jb. Syst. 14: 429-482, pl. 32.

Lenz, H. \& F. Richters, i88i. Beitrag zur Krustaceenfauna von Madagascar. - Abh. Senckenb. naturf. Ges. 12: 42I-428, I pl.

Leone, C. A., I950. Serological systematics of some palinuran and astacuran Crustacea. - Biol. Bull. Woods Hole 98: I22-I27.

LIU, J. Y., I959. Notes on the economic macrurous crustacean fauna of the Yellow Sea and the East China Sea. - Oceanol. Limnol. Sinica 2 (I) : 35-42.

Lucas, H., 1836. Langouste, Palinurus. - Dict. pittor. Hist. nat. 4: $343-345$, pl. 292 fig. 7.

McNeill, F. A., I929. Studies in Australian Carcinology. No. 3 - Rec. Aust. Mus. 17 : I44-I56, textfig. I-4, pl. 35-37.

MAKI, M. \& H. TsuchiYA, I923. A monograph of the Decapod Crustacea of Formosa. Rep. Dept. Agric. Govt. Research Inst. Formosa 3: I-I I, I-215, I-4, pl. I-24.

Man, J. G. DE, I9I6. Families Eryonidae, Palinuridae, Scyllaridae and Nephropsidae. The Decapoda of the Siboga Expedition. Part III. - Siboga Exped. Mon. 39 (a 2) : I-I22, pl. I-4. 
Martens, E. von, I872. Ueber Cubanische Crustaceen nach den Sammlungen Dr. J. Gundlach's. - Arch. Naturgesch. 38 (I) : 77-r47, pl. 4, 5.

- 1876 . Ueber die Thierwelt der besuchten Gegenden im allgemeinen. - Preuss. Exped. Ost-Asien, Zool. 1: 1-412, pl. I-I5.

Masuda, T., I954. On the antennule flagella of the Japanese Spiny Lobster, Panulirus japonicus (v. Siebold), as an age-determinant. - Bull. Japan. Soc. sci. Fish. 19: I007-IOII, fig. I.

Matsui, K., I955. The electrocardiogram of the lobster, Panulirus japonicus. - Sci. Rep. Tokyo Kyoiku Daig. (B) 7: 231-256, fig. I-I9.

- 1955 . Spontaneous discharges of the isolated ganglionic trunk of the lobster heart (Panulirus japonicus). - Sci. Rep. Tokyo Kyoiku Daig. (B) 7: 257-268, fig. I-5.

- 1957. Effects of some ions. Spontaneous discharges of the isolated ganglionic trunk of the lobster heart (Panulirus japonicus). II. -- Sci. Rep. Tokyo Kyoiku Daig. (B) 8: I48-173, fig. I-I2.

Matsui, K. \& T. Shibuya, 1958. Effects of some drugs on the spontaneous activity of the isolated ganglionic trunk of the lobster heart (Panulirus japonicus). - Japan. Journ. Zool. 12: 189-20I, fig. I-8.

Mifrs, E. J., I880. Crustacea Anomura and Macrura (except Penaedea). On a collection of Crustacea from the Malaysian region. - Part. III. - Ann. Mag. nat. Hist. (5) 5 : $370-384$, pl. $14,15$.

Milne EDwards, A., I868. Description de quelques Crustacés nouveaux provenant des voyages de M. Alfred Grandidier à Zanzibar et à Madagascar. - Nouv. Arch. Mus. Hist. nat. Paris 4: 69-92, pl. I9-21.

Milne Edwards, H., 1837. Histoire naturelle des Crustacés, comprenant l'anatomie, la physiologie et la classification de ces animaux 2 : I-532.

Monod, T. \& G. Petit, I929. Palinuridae. Crustacea. II. In : G. Petrt, Contribution à l'étude de la faune de Madagascar. - Faune Colon. Franç. 3: 269-29r, fig. I-9.

Nakamura, S., 1937. Fishing and pond rearing in Panulirus japonicus. - Suisankenkyûsi 32 (9).

-, 1940. Ecological studies on the spiny lobster, Panulirus japonicus (v. Siebold), with special reference to its conservation, I. - Journ. Imp. Fish. Inst. 34: IOI-II3, figs. I, 2 .

Nakazawa, K., I9I7. On the metamorphosis of Panulirus japonicus. - Zool. Mag. (= Dobuts. Zasshi), Tokyo 29: 259-267, I pl.

Niryama, H., 1936. The chromosomes of a Japanese Spiny Lobster, Panulirus japonicus (V. Siebold). - Journ. Fac. Sci. Hokkaido Univ. (6, Zool.) 5 : 2I-28, fig. I-I2.

- I936a. The chromosomes of Panulirus japonicus (de Haan). (A preliminary note). - Jap. Journ. Genet. 12: 53 .

- I959. A comparative study of the chromosomes in decapods, isopods and amphipods, with some remarks on cytotaxonomy and sex-determination in the Crustacea. - Mem. Fac. Fish. Hokkaido Univ. 7: I-60, pl, I-I4.

Ohshima, Y., I935. On the habitat of Panulirus japonicus. - Yôsyokukaisi (Journ. Jap. Soc. Aquicult.) 5: 75-83.

- , r941. Some ecological aspects on Panulirus japonicus. - Suisangakukaihô 8: $231-238$.

-1 1942. On the phyllosomes of the genus Panulirus. - Suisangakukaihô 9: 36-44.

- I948. A consideration on the period of metamorphosis and the age in spiny-lobster, Panulirus Japonicus v. Siebold. - Bull. Japan. Soc. sci. Fish. 13: 210-212, fig. I.

OkadA, Y., I951. Annotated list of animals and plants of Mie Prefecture, Japan : 4 pp., I -532 , pls. I-5.

OkadA, Y. \& K. Kato, 1946. On the migration of P. japonicus. Studies on the Japanese spiny lobster, Panulirus japonicus (v. Siebold) I. - Short Rep. Res. Inst. nat. Resources 1: I-IO. 
OKadA, Y. \& I. Kubo, 1946. Sex-ratio, biological minimum size, and body-length and body-weight compositions. Studies on the Japanese spiny lobster, Panulirus japonicus (v. Siebold). II. - Short Rep. Res. Inst. nat. Resources 4: I-9.

-, I948. Puerulus and young I. Studies on the Japanese spiny lobster, Panulirus japonicus (v. Siebold). V. - Misc. Rep. Res. Inst. nat. Resources 12: 20-24, fig. I, 2.

- 1950. Comparison of puerulus, young and adult. Studies on the Japanese spiny lobsier. Panulirus japonicus (V. Siebold). VI. - Misc. Rep. Res. Inst. nat. Resources 15: 4I-46, fig. 3, 4 .

Okada, Y., I. Kubo \& K. TAGaki, 1947. Spawning. Studies on the Japanese spiny lobster, Panulirus japonicus (von Siebold). III. - Zool. Mag. Tokyo 57 (3): 27, 28.

Okada, Y. K., I. TAKI, T. SAKaI \& T. ABE, I958. Illustrated pocket book of the Japanese fauna in colour (ed. 9) 2: 2 pp., (I)-(I5), I-286, (I)-(82), fig. I-500, unnumbered figs.

OKuDA, Y., I919. On the extractive matters of Palunirus japonicus and Loligo breekeri. - Journ. Coll Agric. Univ. Tokyo 7 : 55-67.

Ortmann, A., r89i. Die Abteilungen der Reptantia Boas: Homaridea, Loricata und Thalassinidea. Die Decapoden-Krebse des Strassburger Museums, mit besonderer Berücksichtigung der von Herrn Dr. Döderlein bei Japan und den Liu-Kiu-Inseln gesammelten und z.Z. im Strassburger Museum aufbewahrten Formen. III. Theil. - Zool. Jb. Syst. 6: 1-58, pl. I.

Parisi, B., I9I7. Galatheidea e Reptantia. I Decapodi Giapponesi del Museo di Milano. V. - Atti Soc. Ital. Sci. nat. 56: I-24, fig. I-7.

PARKer, T. J., 1884. On the structure of the head in Palinurus, with especial reference to the classification of the genus. - Trans. Proc. New Zeal. Inst. 16: 297-307, pl. 25 .

Pesta, O., 1915. Bemerkungen zu einigen Langusten (Palinuridae) und ihrer geographischen Verbreitung. - S. B. Akad. Wiss. Wien 124 (I) : 3-12, 2 textfigs., I pl.

Pferfer, G., I881. Die Panzerkrebse des Hamburger Museums. - Verh. naturw. Ver. Hamburg 5 : 22-55

PING, C., I930. Zoological notes on Amoy and its vicinity. - Bull. Fan Mem. Inst. Biol. 1: 127-142, I map.

Popovici, Z. \& V. ANGelescu, 1954. La economia del mar y sus relaciones con la alimentacion de la humanidad. - Publ. Ext. cult. did. Mus. Argent. Ci. nat. 8 (I) : i-xiv, I-659, textfig. I-49, pl. I-I2; (2) : i-xi, 660-I056, textfig. 50-57.

Quox, J. R. C. \& P. Gaimard, i824-26. Zoologie. In: L. DE Freycinet, Voyage autour du monde, entrepris par ordre du Roi, sous le ministère et conformément aux instructions de S. Exc. M. le Vicomte du Bouchage, secrétaire d'état au département de la Marine, exécuté sur les corvettes de S. M. l'Uranie et la Physicienne, pendant les années 1817, 1818, I819 et 1820: 1-712, pl. I-96.

Rapson, A. M., 1962. The tropical crayfish (Panulirus ornatus Fabricius) in southern Papuan waters. - Fish. Bull. Dept. Agric. Stock Fisheries Port Moresby 2: 6 pp., I-17, I, 2, 2 pp., 2 maps.

Rathbun, M. J., I902. Japanese stalk-eyed Crustaceans. - Proc. U.S. Nat. Mus. 26: 23-55, fig. 1-24.

-_, 1906. The Brachyura and Macrura of the Hawaiian Islands. - Bull. U.S. Fish. Comm. 23 : 827-930, textfig. I-79, pl. 1-24.

ReEd, E. P., 1954. Palinuridae. - Scientia, Valparaiso 21 : 13I-I39, fig. I-9.

Richters, F., I880. Decapoda. In: K. MöвıUs, Beiträge zur Meeresfauna der Insel Mauritius und der Seychellen: 139-178, pl. 15-18

Ride, W. D. L. \& D. L. Serventy, ig6i. The fauna of Western Australia. - Off. Yearb. West. Aust. 1960 (2) : 59-70. 
Schauinsland, H., i899. Drei Monate auf einer Korallen-insel (Laysan): I-7o.

Scheer, B. T. \& M. A. Scheer, 1949. Blood sugar in the spiny lobster Panulirus. Proc. Hawaiian Acad. Sci. 24 : 9.

—. I95I. Blood sugar in spiny lobsters. Part I of hormonal regulation of metabolism in crustaceans. - Physiol. compar. Oecol. 2: 198-209, fig. I-3.

Scheer, B. T., C. W. Schwabe \& M. A. R. Scheer, I952. Tissue oxidations in crustaceans. Part III of the hormonal regulation of metabolism in crustaceans. - Physiol. compar. Oecol. 2: 327-338.

Schwabe, C. W., B. T. Scheer \& M. A. R. Scheer, I952. The molt cycle in Panulirus japonicus. Part II of the hormonal regulation of metabolism in crustaceans. Physiol. compar. Oecol. 2: 310-320, fig. I-4

ShEARD, K., I949. The marine crayfishes (spiny lobsters), family Palinuridae, of Western Australia. With particular reference to the fishery on the Western Australian Crayfish (Panulirus longipes). - Bull. Commonw. sci. industr. Res. Organis. Aust. 247: I-45, I map.

- - I I950. Care in the handling of crayfish. - Fish. Bull. West. Aust. Fish. Dept. 3 : I-I I.

- I954. Report on continuous crayfishing tests, 1947-48, - Bull. West. Aust. Fish. Dept. 5 : 1-54.

-, I962. The Western Australian crayfishery I944-I96I: I-I07, fig. I-29.

Sheard, K. \& H. G. Dicks, 1949. Skin lesions among fishermen at Houtman's Abrolhos, Western Australia, with an account of erysipeloid of Rosenbach. - Medic. Journ. Australia 2: $352-354$.

Shino, S. M., I950. Studies on the embryonic development of Panulirus japonicus (von Siebold). - Journ. Fac. Fish. Univ. Mie 1: I-I68, pl. I-25.

Siebold, G. T. 1) DE, I824. De historiae naturalis in Japonia statu, nec non de augmento emolumentisque in decursu perscrutationum exspectandis dissertatio, cui accedunt Spicilegia Faunae Japonicae: I-I6 (Bataviae).

Siebold, P. F. DE, I826. De historiae naturalis in Japonia statu nec non de augmento emolumentisque in decursu perscrutationum exspectandis dissertatio, cui accedunt Spicilegia Faunae Japonicae: I-20 (Wirceburgi).

- 1897 . Nippon. Archiv zur Beschreibung von Japan und dessen Neben- und Schutzländern Jezo mit den südlichen Kurilen, Sachalin, Korea und den Liukiu-Inseln (ed. 2) 1 : i-XXxv, I-42I, fig. I-5I, I map, I frontisp., I portrait; 2 : i-vii, I-342, fig. I-47.

Smith, F. G. W., I958. The spiny lobster industry of Florida. - Educat. Ser. Florida Board Conserv. $11: 5-34$, fig. I-I4.

Smith, R. O., I948. Survey of the fisheries of the former Japanese mandated islands. Fisher. Leafl. U.S. Fish. Wildlife Serv. 273 : i-vi, I-105, fig. I-50, maps.

Stimpson, W., I860. Prodromus descriptionis animalium evertebratorum, quae in expeditione ad Oceanum Pacificum Septemtrionalem, a Republica Federata missa, C. Ringgold et J. Rodgers ducibus, observavit et descripsit. - Proc. Acad. nat. Sci. Philad. 1860: $22-48$.

Takayama, I., 1939. On a tagging method of Panulirus japonicus. - Suisankenkyûsi 34 (4).

TAYLOR, S. J., I956. A survey of the Western Australian crayfishing industry 1948-55. - University Studies in History and Economies 2: 94-II7.

Terao, A., I9I5. Moulting of Panulirus japonicus. - Zool. Mag. Tokyo 27 (315).

-, 1919. On the development of Panulirus japonicus (v. Siebold). - Rep. Imp. Fish. Inst. Tokyo 14 (5) : I-7, pl. I-4.

- $1925 . \mathrm{Zu}$ Piatakovs Entdeckung eines Dorsalorgans bei Potamobius. - Zool. Anz. 65: I, 2 .

I) error for P.F. 
- 1929. On the embryonic development of the spiny lobster, Panulirus japonicus (v. Siebold). - Japan. Journ. Zool. 2: 387-449, pl. II-I5.

Thompson, D' A. W., I901. A catalogue of Crustacea and of Pycnogonida contained in the museum of University College, Dundee: I-56.

Tokuhisa, M., I9I4. Panulirus japonicus taken from Nanao Bay. - Suisankenkyûsi 9: $4 \mathrm{I}$.

Uтіломі, H., I956. Coloured illustrations of sea shore animals of Japan: i-xvii, I-I67, pl. I-64, i-xii.

White, A., I847. List of the specimens of Crustacea in the collection of the British Museum: i-viii, I-I43.

Whitelegge, T., I 897 . The Crustacea of Funafuti. The Atoll of Funafuti, Ellice Group: its zoology, botany, ethnology, and general structure based on collections made by Mr. Charles Hedley, of the Australian Museum Sydney, N.S.W. - Mem. Aust. Mus. 3: I25-15I, pl. 6, 7 .

Wiersma, C. A. G. \& S. H. Ripley, I952. Innervation patterns of Crustacean limbs.Physiol. compar. Oecol. 2: 39I-405, fig. I-6.

YAMA JI, I., 1959. The plankton of Japanese coastal waters : 4 pp., I-230, textfigs., pl. I-8.

YoRK, B. A., I949. The crayfish industry: I-IO (mimeographed).

Yoshida, H., I94I. Important marine shrimps and lobsters of Tyōsen (Korea). - Bull. Fish. Exper. Sta. Tyōsen 7: I-36, textfig. I-15, pl. I-13.

Yosir, N., 193I. Note on a Japanese Spiny Lobster with an antennule regenerated in place of the eye. - Journ. Fac. Sci. Univ. Tokyo Zool. 2: 445-447, fig. I-3.

- 1933. Notes on a twisted antenna of Japanese Spiny Lobster caused by split and spiral annulation. - Journ. Fac. Sci. Univ. Tokyo Zool. 3: 233-237, fig. I-8.

\section{Explanation of THE PLATES}

\section{Pl. I}

Panulirus japonicus (Von Siebold), of paralectotype, Japan, 1823-1830, P. F. von Siebold (RMNH no. D. 5624), $\times$ 0.37. H. Heijn del.

P1. 2

Panulirus marginatus (Quoy \& Gaimard), \&ิ, near Waimea Bay, Oahu, Hawaiian Islands, 3I August I947, F. M. Bayer (RMNH no. D. I4508), nat. size. H. Heijn del.

\section{P1. 3}

Panulirus pascuensis Reed, \&, Cook Bay, Easter Island, 29 December I934, "Mercator" (ISNB), $\times$ 0.44. W. C. G. Gertenaar del.

\section{Pl. 4}

Panulirus cygnus George, \& paratype, Rottnest Island, Western Australia, 17 February I959, R. W. George (RMNH no. D. 13107), $\times$ 0.44. In life the central area of the carapace is not darker than the lateral parts as shown in the plate. W. C. G. Gertenaar del.

P1. 5

Fig. a, Panulirus longipes femoristriga (Von Martens), \$, Sorido, Biak Island, New Guinea, 4 February 1955, L. B. Holthuis (RMNH no. D. I7447), X o.6. Fig. b, Panulirus longipes longipes (A. Milne Edwards), Ceylon, G. H. P. De Bruin (RMNH no. D. I869I), fourth leg of female, $X$ 0.9. W. C. G. Gertenaar del. 


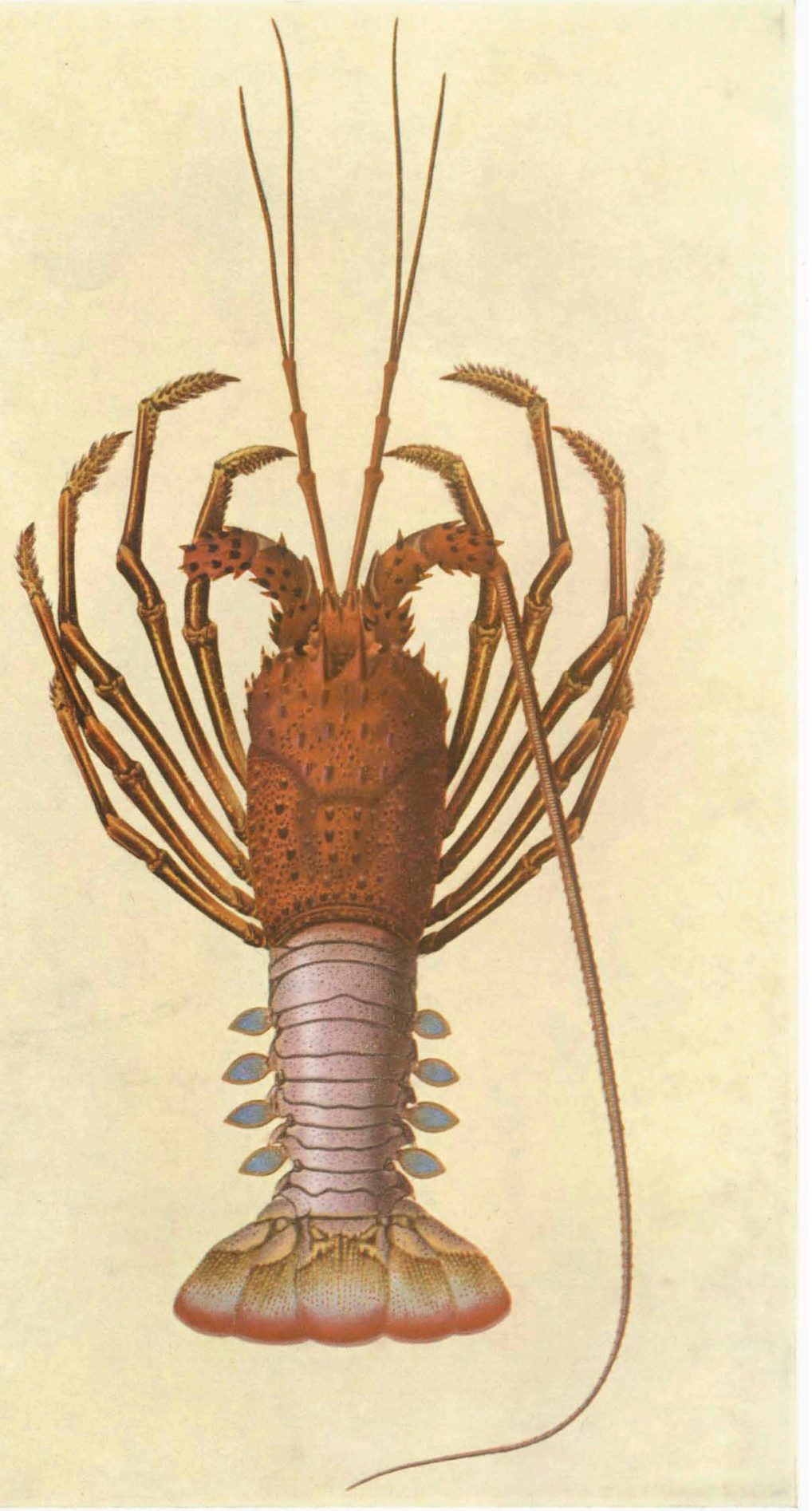




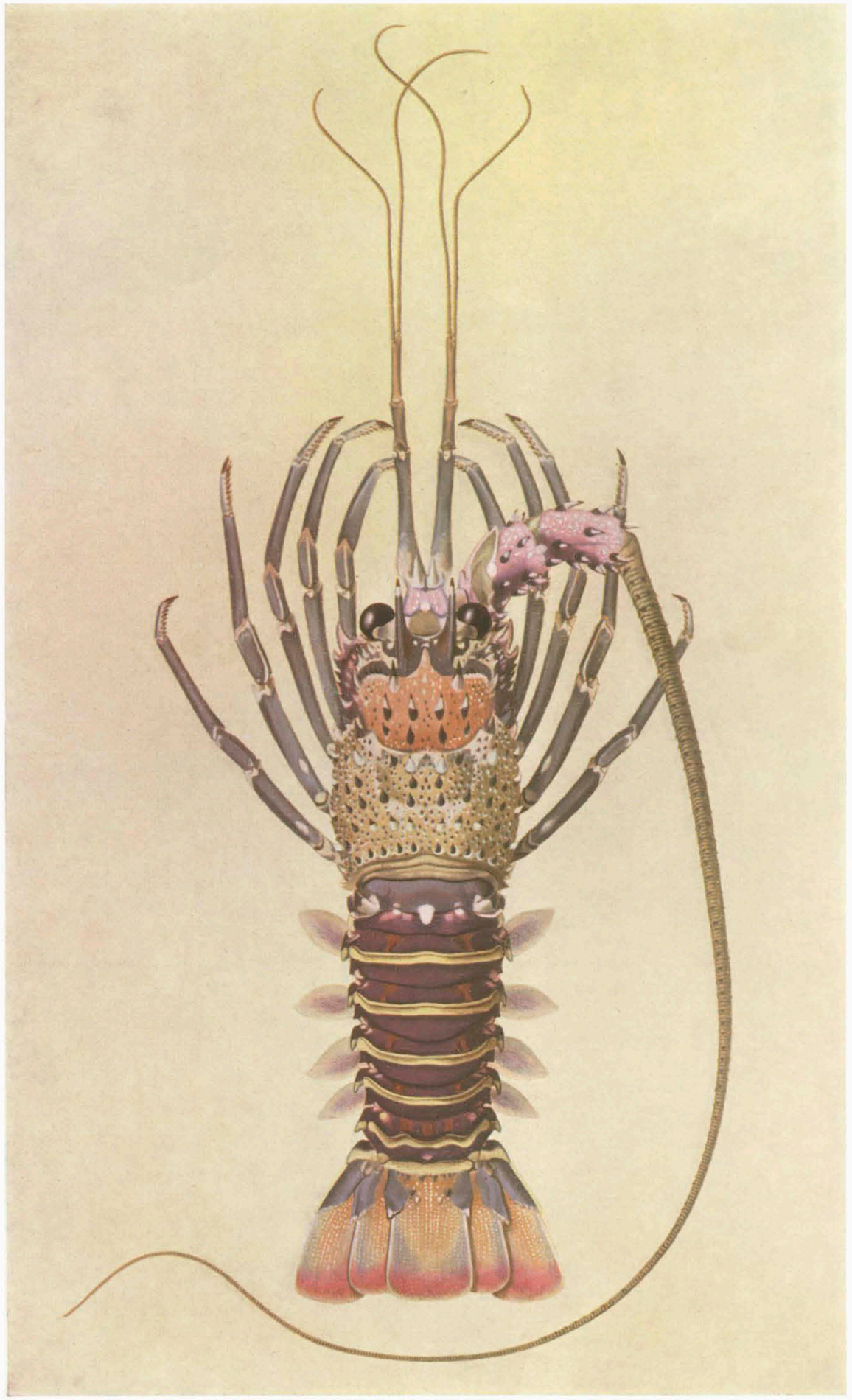




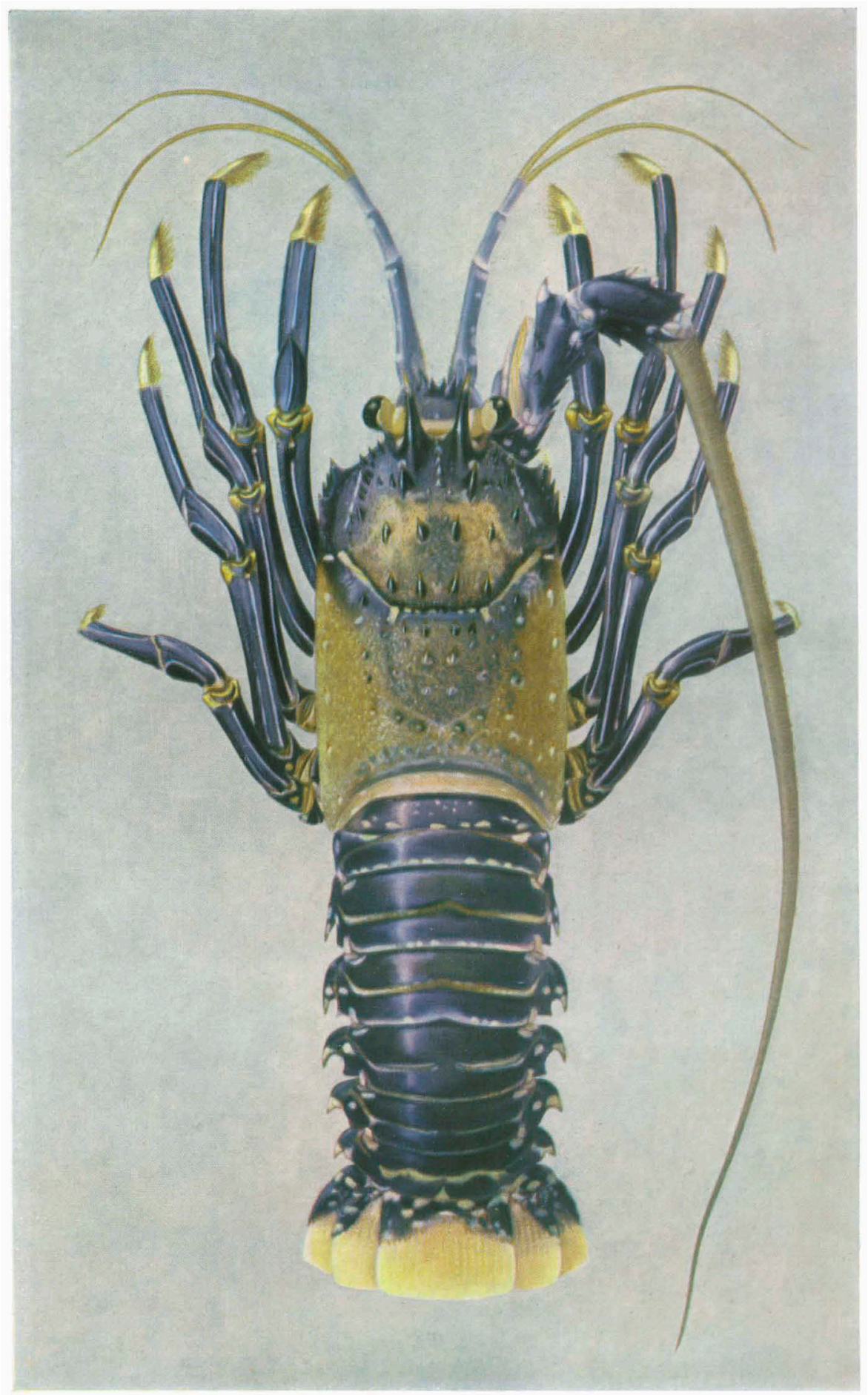




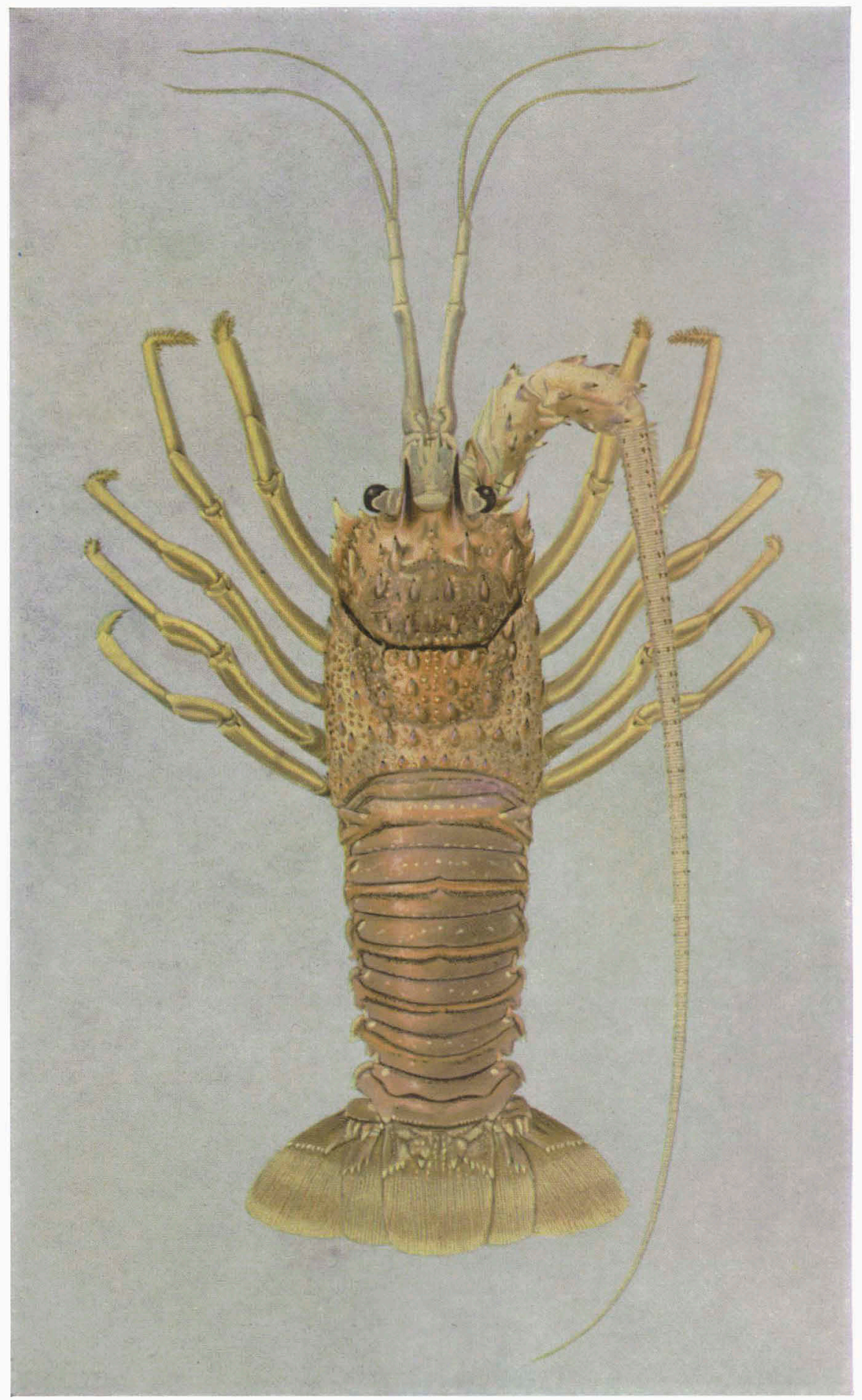




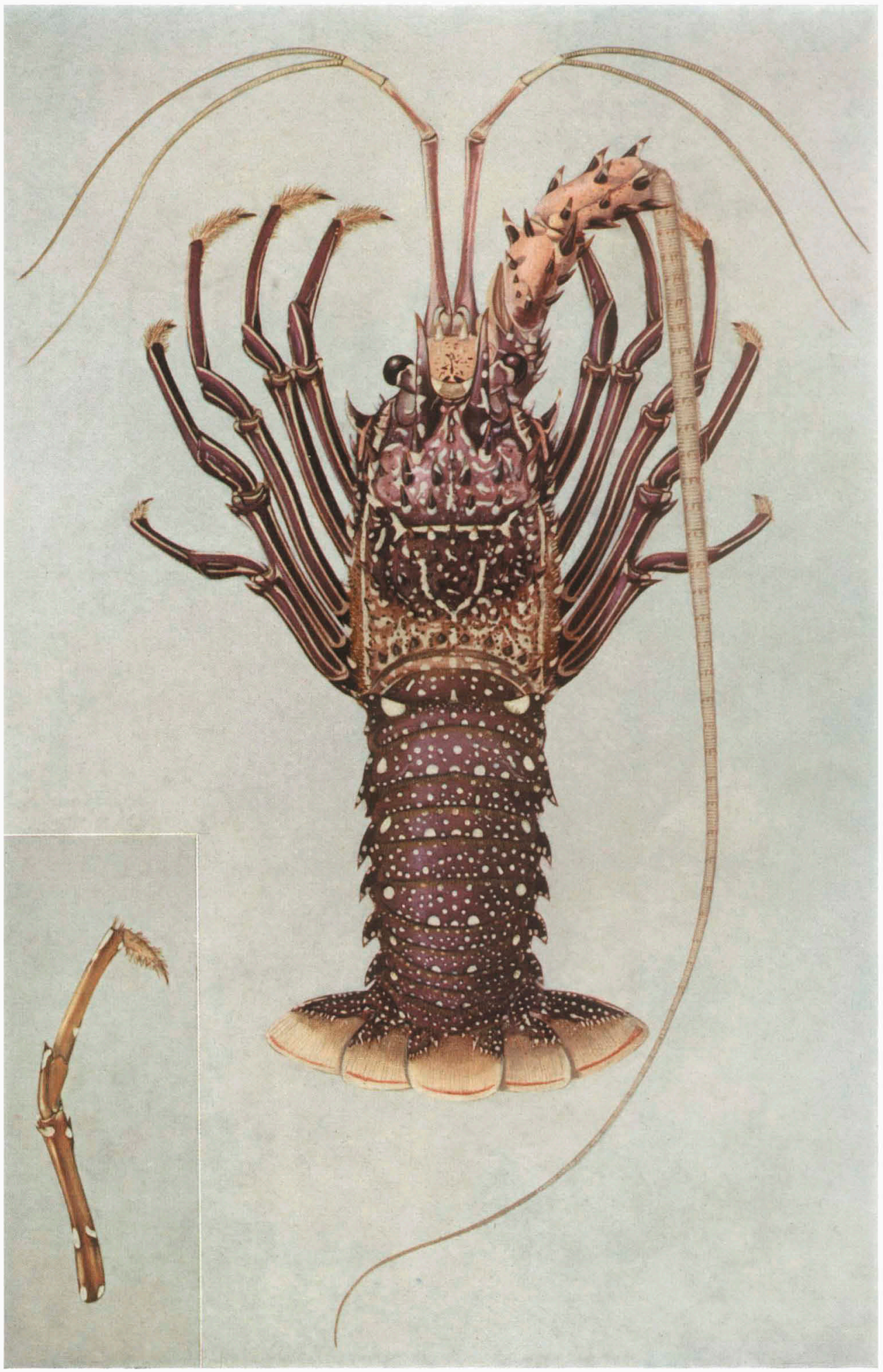

